Article

\title{
Cumulative Effects Analysis of the Water Quality Risk of Herbicides Used for Site Preparation in the Central North Island, New Zealand
}

\author{
Daniel G. Neary ${ }^{1,2, *}$ and Brenda R. Baillie ${ }^{2}$ \\ 1 USDA Forest Service, Rocky Mountain Research Station, Flagstaff, AZ 86001, USA \\ 2 SCION Forest Research Institute, Rotorua 3046, New Zealand; Brenda.Baillie@scionresearch.com \\ * Correspondence: dneary@fs.fed.us; Tel.: +1-928-556-2176
}

Academic Editor: Jiangyong $\mathrm{Hu}$

Received: 17 September 2016; Accepted: 22 November 2016; Published: 6 December 2016

\begin{abstract}
Herbicide use varies both spatially and temporally within managed forests. While information exists on the effects of herbicide use on water quality at the site and small catchment scale, little is known about the cumulative effects of herbicide use at the landscape scale. A cumulative effects analysis was conducted in the upper Rangitaiki catchment (118,345 ha) in New Zealand, to determine the risk to water quality from two herbicides commonly used for post-plant weed control: terbuthylazine and hexazinone. Data from a 12.5 ha catchment study within the Rangitaiki Basin, where these herbicides were aerially applied in two consecutive years, were used to model herbicide concentrations entering the Rangitaiki River for the remaining treated areas in the catchment for the same two spray seasons. A spreadsheet model routed herbicide residues from their point of entry into the river to a flow gauge on the Rangitaiki River. Modeling of chemical residue loadings and concentrations of terbuthylazine and hexazinone indicated that potential herbicide residues in stream waters would be mainly below analytical detection limits and pose no risk to the aquatic environment or human health and safety. Safety factors for drinking water quality standards, aquatic organisms, and human Acceptable Daily Intake levels were very large.
\end{abstract}

Keywords: hexazinone; terbuthylazine; cumulative effects; water quality; New Zealand

\section{Introduction}

\subsection{Water Quality from Forests}

Water quality is a relative concept that is based on measurable physical, chemical, and biological characteristics in relation to specific uses such as human consumption, crop irrigation, livestock watering, fisheries maintenance, recreation, and aquatic habitat [1]. As water moves through a catchment, it interacts with ecosystem components and transports dissolved gases, cations and anions, organic compounds, trace metals, sediment particles, microscopic organisms, and introduced anthropogenic chemicals such as fertilizers and pesticides [2]. Water quality integrates the current state of ecosystem health as well as the effects of disturbance within the aquatic ecosystem. Understanding of the movement of water through forest landscapes then provides the scientific foundation for evaluating and rating water quality in both natural and disturbed forests [3-5].

Forested watersheds produce sustainable supplies of high quality water based on two fundamental reasons [6]. First, forests grow under climate conditions that usually produce consistent amounts of high quality streamflow. Although streams and lakes originating in forests are affected by drought, they are still more reliable than those with sources in other ecosystems. The precipitation needed to promote and sustain forest growth is also adequate to sustain stream baseflows, which is important for maintaining aquatic habitat [3-6]. Exceptions occur on the lower end of the precipitation 
range for forests $\left(<1000 \mathrm{~mm} \cdot\right.$ year $^{-1}$; [5]). Second, forests generally have lower levels of physical and chemical disturbance depending on global location, climate, management history, etc., so they are able to yield higher quality water than alternative uses such as agricultural or urban catchments $[7,8]$. The challenge to forest land managers is to conduct management operations while keeping water quality within the acceptable range for current and projected uses $[4,9]$.

\subsection{Herbicide Fate Studies in Forests}

Herbicides are used in managed forests, primarily for control of competing vegetation during the establishment phase of the forest growing cycle [10-16]. The fate and movement of herbicides in forested catchments has been fairly well documented, particularly by research in the USA and Australia [17-20]. Some contradictory results have been produced due to differences in application rates, distribution equipment, and levels of Best Management Practices. For example, the highest concentration of hexazinone reported in streamflow in the literature $\left(2400 \mu \mathrm{g} \cdot \mathrm{L}^{-1}\right.$ or parts per billion) was due to aerial application of herbicide pellets into a perennial stream in Alabama [21]. In contrast, a similar aerial application in Tennessee did not produce any detectable levels of hexazinone in streamflow and springflow during a seven-month monitoring period [22]. Whether applied aerially or through ground application, peaked herbicide concentrations were usually detected on the day of application or in storm run-off, particularly in the first few weeks following herbicide application (i.e., [23-30]). Otherwise, herbicide use in forests has generally resulted in low concentrations in streamflow ( 0 to $4 \mu \mathrm{g} \cdot \mathrm{L}^{-1}$ ) for short durations, often below detection limits $[18,19,22,23]$. All of these studies have been conducted at the level of small stands or catchments. None have addressed the issue of multiple herbicide applications, or involved systematic efforts to scale up the results to larger landscapes to assess cumulative risks to water quality risk as recommended by Boyle et al. [31].

\subsection{Cumulative Effects}

Cumulative effects or impacts were defined in 1971 by the United States Code of Federal Regulation [32] as: "the impact on the environment which results from the incremental impact of the action when added to other past, present, and reasonably foreseeable future actions regardless of what agency (Federal or non-Federal) or person undertakes such other actions. Cumulative impacts can result from individually minor but collectively significant actions taking place over a period of time."

Any analysis of the impacts of forest management activities such as herbicide application requires the acknowledgment that managed forest ecosystems are affected by multiple disturbances of similar and dissimilar natures that are complex, may interact with each other, occur over expanded and permeable boundaries, and have broad time horizons and inherent time lags [33]. These system attributes result in cumulative effects and are central to the theory of environmental change and the idea of ecosystems and their response to disturbance [34-36]. The framework of cumulative environmental change is particularly well suited to analyzing the impacts of herbicide use to water quality at a landscape scale since herbicides are applied as part of a suite of disturbances that might include tree harvesting, mechanical site disturbance, vegetation removal, fire, planting, and fertilizer application $[11,37,38]$.

Spaling's 1994 paper [33] on cumulative effects assessment approaches the topic from the concept of environmental change theory which is based on ecosystem disturbance concepts in geography [34,39,40]; among others). The main types, characteristics, and examples in forestry are listed in Table 1. Of the cumulative effects types listed in Table 1, space and time crowding are the most common impacts on water quality associated with herbicides. Synergistic effects are rare and often difficult to quantify. Two herbicides in the same tank mix can affect different target weeds. Although their effects on water quality can be additive, they are usually not synergistic, antagonistic, or multiplicative [11-16]. In addition, water quality standards are normally set for individual chemicals and not combinations. Indirect effects on water quality do occur and they can be either negative or positive [14]. 
Table 1. Cumulative effects types, characteristics, and examples adapted from Spaling [33].

\begin{tabular}{cll}
\hline Type & \multicolumn{1}{c}{ Characteristics } & \multicolumn{1}{c}{ Examples } \\
\hline Time Crowding & $\begin{array}{l}\text { Frequent and repetitive activities in the } \\
\text { same time frame }\end{array}$ & $\begin{array}{l}\text { Multiple herbicide applications within a } \\
\text { catchment the same day }\end{array}$ \\
\hline Space Crowding & Management activities on the same sites & $\begin{array}{l}\text { Harvesting, site preparation, burning, and } \\
\text { chemical applications on the same stand }\end{array}$ \\
\hline Synergistic & $\begin{array}{l}\text { Effects from different activities that } \\
\text { multiply the impact }\end{array}$ & $\begin{array}{l}\text { Multiplicative effects of herbicides or fertilizers } \\
\text { on vegetation \& water quality }\end{array}$ \\
\hline Indirect & $\begin{array}{l}\text { Secondary effects not directly related to } \\
\text { an activity }\end{array}$ & $\begin{array}{l}\text { Nitrogen release into groundwater after } \\
\text { harvesting mature stands }\end{array}$ \\
\hline Nibbling & $\begin{array}{l}\text { Incremental reductions in water quality } \\
\text { Time Lag }\end{array}$ & $\begin{array}{l}\text { Changes in water quality from inputs of } \\
\text { pollutants along a stream course }\end{array}$ \\
\hline management activities & $\begin{array}{l}\text { Delayed movement of fertilizers or herbicide } \\
\text { residues into streams }\end{array}$ \\
\hline Trigger/Threshold & $\begin{array}{l}\text { Changes in system behavior and } \\
\text { characteristics }\end{array}$ & $\begin{array}{l}\text { Chemical drift from fertilized paddocks into } \\
\text { forested areas }\end{array}$ \\
\hline Fragmentation & $\begin{array}{l}\text { Change in land use the breaks up } \\
\text { continuity of an ecosystem }\end{array}$ & $\begin{array}{l}\text { Urbanization of forest lands or conversions } \\
\text { to agriculture }\end{array}$ \\
\hline
\end{tabular}

Nibbling definitely occurs along stream courses and is caused by a number of nonpoint source pollutants, not just herbicides [41]. Sediment and nutrients are the biggest contributors to nibbling effects. Time lag enters into herbicide cumulative effects analyses when residues are substantially delayed in entering groundwater and streams or lakes. However, the concentrations are usually quite small and do not approach New Zealand or international water quality standard limits. Cross boundary effects can occur with aerial applications and often can be the major source of inputs to water despite buffers and computer control of applications. Trigger and threshold effects are not important considerations in herbicide cumulative effects analyses although drought can delay residue movement in soils and excessive rainfall can wash off more herbicide residues into surface waters. In the latter case, herbicide concentrations are likely to be quite low due to dilution effects [17]. Lastly, fragmentation effects do not enter into herbicide cumulative effects analyses since herbicides by themselves do not fragment landscapes. One aspect of herbicide application in already fragmented landscapes can be higher incidences of cross-boundary effects.

Studies by Beanlands et al. [42] and Orians [43] concluded that the key components of managing cumulative effects are: (1) determining if cumulative effects are likely; (2) identifying the most appropriate warning signals that cumulative effects are occurring; and (3) attempting to reverse cumulative effects once they have begun to influence ecosystems.

In landscapes that have intense and extensive forest management, the big question for this context becomes "Are there water quality effects that occur from multiple disturbances within the same landscape?" This is where a cumulative effects analysis becomes very important for both forest managers and the general public. Since herbicide use in planted forests is controversial because of its potential to affect water resources, a cumulative effects analysis of multiple applications of the same herbicide or combinations of herbicides within a large catchment is an important tool for assessing herbicide application impacts on water quality.

In New Zealand, hexazinone and terbuthylazine accounted for $50 \%$ of the total annual herbicide loading on planted forest landscapes $\left(447.4 \times 10^{3} \mathrm{~kg}\right)$ [15]. The authors concluded that when used operationally and according to label instructions, these two herbicides are unlikely to have any negative impacts on the planted forest environment or human health and safety. The authors did highlight the sparsity of information and a need for further research in this area [15]. This study is directed at meeting that need. 
The objective of this study was to model the cumulative effects of hexazinone and terbuthylazine aerial applications on water quality over two successive seasons (2013-2014). The upper Rangitaiki River catchment was used as the basis for this study since planted forests are the predominant land use in the catchment, herbicide application data was available for modeling purposes and a flow gauging station on the Rangitaiki River at Murupara, New Zealand (Rangitaiki flow gauge), provided streamflow data.

\subsection{Cumulative Effects Hypotheses}

Several hypotheses were formulated for this cumulative effects analysis. The analysis was designed to evaluate time and space crowding, and time lag cumulative effects. It was not designed to assess the other effect types noted in Table 1. Time lag from the beginning to the end of the seasonal applications and from Year 1 to Year 2 was considered but not found to be significant. However, it was considered in routing of herbicide residues from application sites to the analysis point at Murupara. In this case, time lags induced by long distances were factored into the analysis. The study hypotheses were:

H1 Some localized and short duration cumulative effects due to time crowding, space crowding, and time lag will be observed in the model outputs.

H2 Dispersed aerial herbicide applications will have no adverse effect on water quality in the upper Rangitaiki River Basin.

\section{Materials and Methods}

\subsection{Study Catchment}

The cumulative effects study was undertaken in the central North Island region of New Zealand in the upper Rangitaiki River catchment (Figure 1). The Rangitaiki River originates in the Ahimanawa Range (1034 $\mathrm{m}$ a.s.l.) and flows across the Kaingaroa Plateau to the Rangitaiki flow gauge (200 $\mathrm{m}$ a.s.l.) and thence to the Bay of Plenty. The Rangitaiki flow gauge provided a convenient downstream limit for the upper Rangitaiki catchment for the purposes of this study. The catchment area above the Rangitaiki flow gauge is 118,345 ha. Most of the upper catchment is underlain by rhyolitic ignimbrite [16]. There are small areas of pumice alluvium throughout the Rangitaiki River Basin with minor greywacke intrusions on the eastern side of the catchment. Pumice soils predominate throughout the upper catchment $[16,44,45]$. There are insufficient data from the Garrett et al. [16] study to factor in soil type differences into the cumulative effects analysis.

The climate of the upper Rangitaiki catchment is classified as a New Zealand temperate mesothermal climate or a warm temperate thorn steppe biome in the Holdridge Life Zone system [46]. Although temperature can affect herbicide degradation, thermal breakdown of herbicide residues was not considered in this analysis due to the lack of sufficient field data. The catchment is exposed to the north, with most of the widespread and heavy rain originating from this direction or from the west in the upper parts of the catchment. Mountain ranges to the south provide some protection from rainfall originating from these directions. Annual rainfall averages $1338 \mathrm{~mm}$ at Murupara, the base of the upper catchment, increasing with elevation to an average of $2325 \mathrm{~mm}$ at Taharua near the headwaters of the Rangitaiki River. Rainfall is distributed evenly throughout the year with the Rangitaiki headwaters experiencing rainfall higher than the monthly average in the winter months [47,48].

Maximum temperatures average $24^{\circ} \mathrm{C}$ in February and $14{ }^{\circ} \mathrm{C}$ in August at Murupara. Low temperatures are typically $16^{\circ} \mathrm{C}$ in February and $7^{\circ} \mathrm{C}$ in August [49]. Average temperatures during the herbicide application months of September through January range from $8.4^{\circ} \mathrm{C}$ in September to $16.3^{\circ} \mathrm{C}$, increasing by 1.5 to $4.0^{\circ} \mathrm{C}$ per month. Planted forests, predominantly Pinus radiata, dominate land cover in the upper Rangitaiki River catchment (Figure 1), (71\% of the land cover). High and low 
producing pasture as well as cropland occupy the upper $21 \%$ of the catchment. Indigenous forest is present in patches along the eastern margin ( $8 \%$ of land cover).

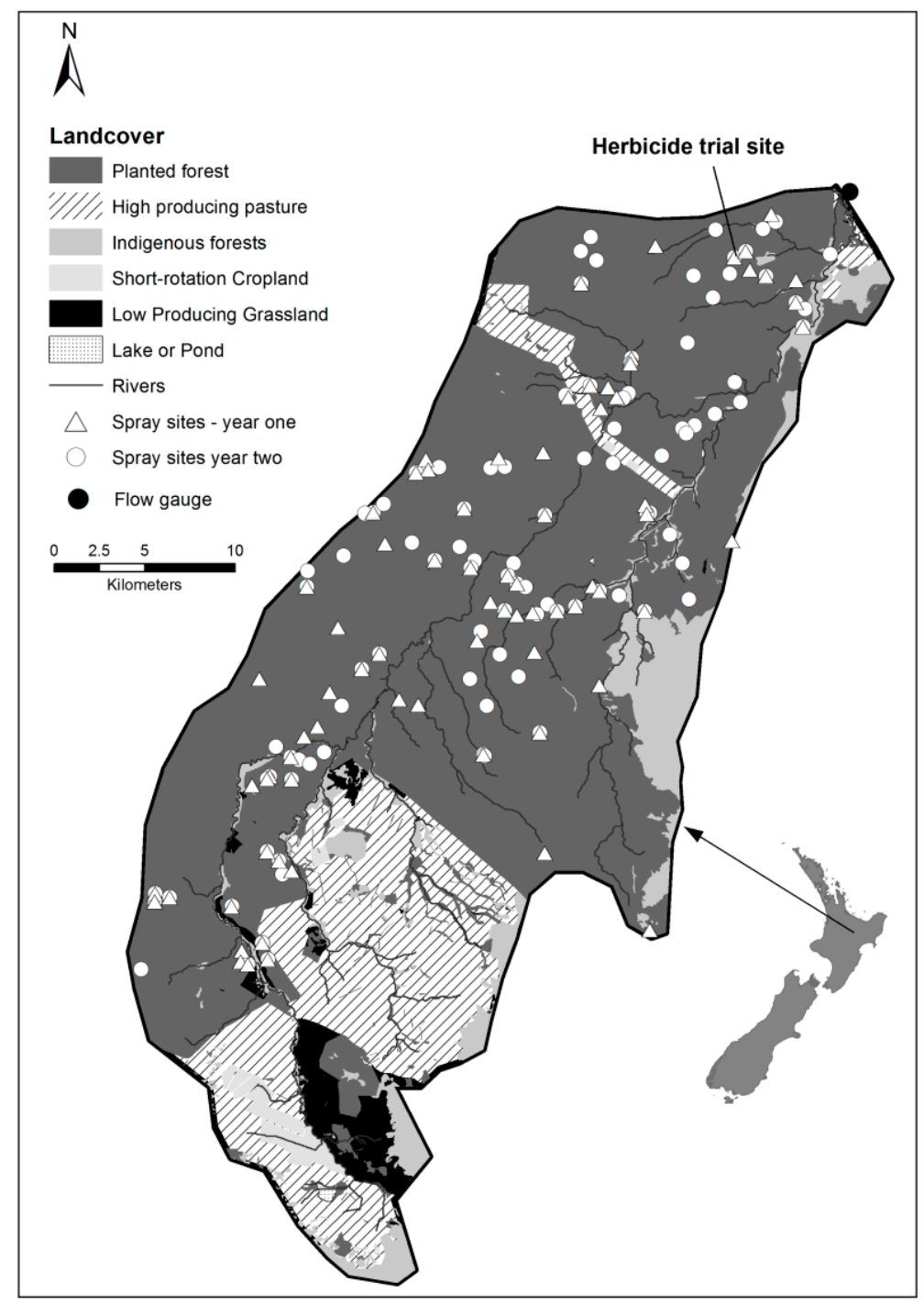

Figure 1. The upper Rangitaiki River catchment study area in the North Island of New Zealand showing the land cover and the sites treated with herbicides in Year 1 and Year 2.

\subsection{Data Bases Used in the Cumulative Effects Model}

\subsubsection{Herbicide Trial}

The data from a trial in a 12.5 ha sub-catchment of the upper Rangitaiki catchment (Figures 1 and 2) to assess the aquatic fate of aerially applied terbuthylazine and hexazinone were used as the basis of the cumulative effects analysis [30]. The sub-catchment was treated in two consecutive years with Release $\mathrm{KT}^{\mathrm{TM}}$ (Orion Crop Protection Limited, Christchurch, New Zealand) (435 g. $\mathrm{L}^{-1}$ terbuthylazine and $65 \mathrm{~g} \cdot \mathrm{L}^{-1}$ hexazinone) at $7.4 \mathrm{~kg} \cdot \mathrm{ha}^{-1}$ and $1.1 \mathrm{~kg} \cdot \mathrm{ha}^{-1}$, respectively [30]. Herbicide concentrations in stream flow were monitored at the trial site for 216 days after treatment in Year $1(2012 / 2013)$. In Year $2(2013 / 2014)$, herbicide concentrations were monitored at the trial site and downstream where the stream entered the Rangitaiki River, $0.5 \mathrm{~km}$ upstream of the flow gauge site, for 170 days after treatment. Full details of the trial including the water sampling strategy and laboratory analyses are in Baillie et al. [30]. 


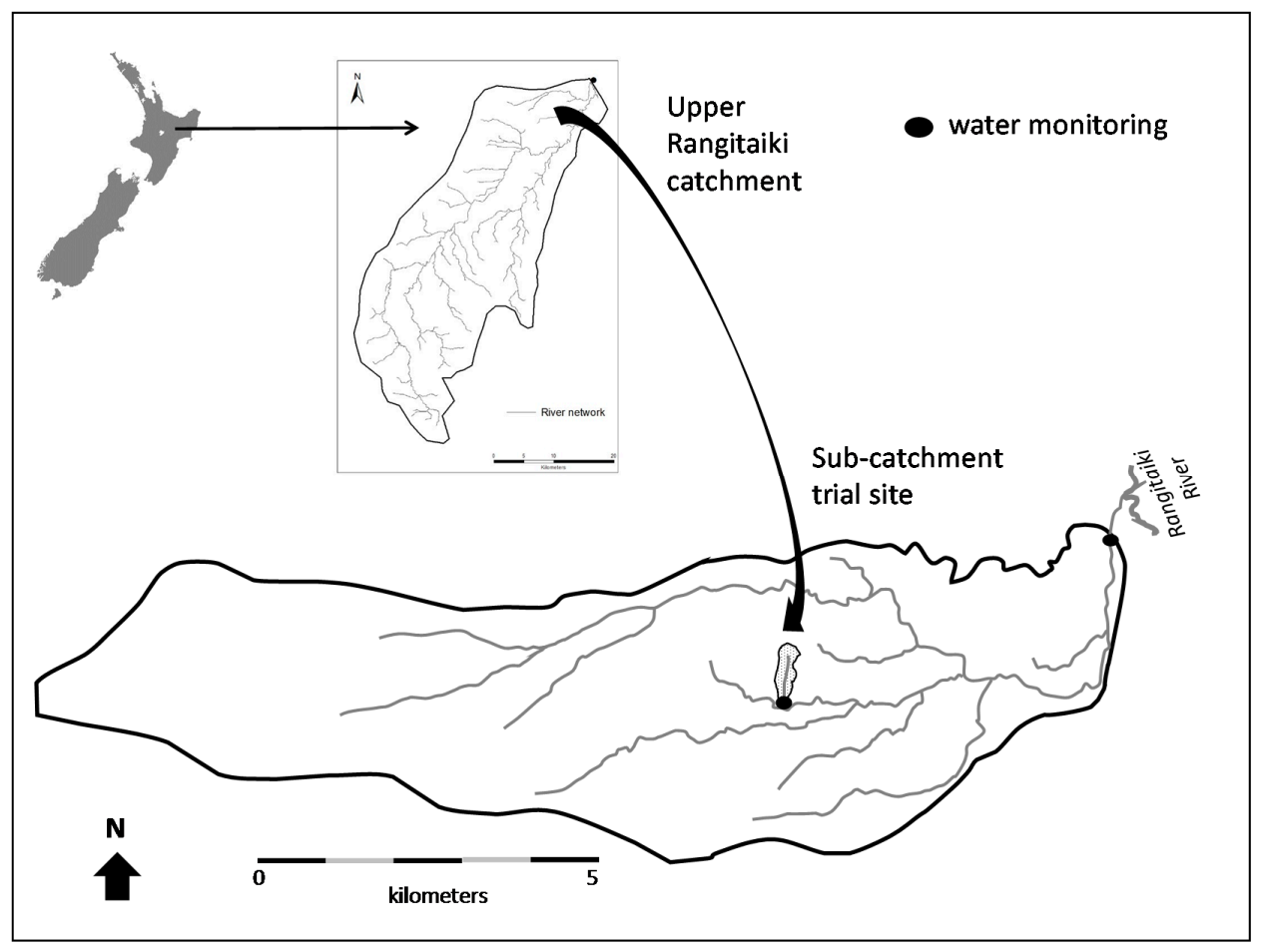

Figure 2. Location of herbicide trial in a sub-catchment of the upper Rangitaiki River catchment, New Zealand. Figure modified from [30].

These data were used to calculate herbicide decay curves. All areas treated with terbuthylazine and hexazinone within the upper Rangitaiki catchment over the same two years as the trial were assumed to provide the same levels of herbicide residues to the streamflow. This was based on the assumption that the herbicides were applied under similar operational conditions as the herbicide trial and followed the same pattern of dilution and residue decay with time. This included the assumption that any high rainfall events (storm events) sampled in the sub-catchment trial and subsequent elevations in herbicide residue concentrations in streamflow occurred across the rest of the sites treated with herbicide within the Rangitaiki catchment. Full details of the trial are in Baillie et al. [30].

\subsubsection{Herbicide Treatment Programme}

The areas treated with terbuthylazine and hexazinone in the upper Rangitaiki catchment in (Year 1 and Year 2) were used in the construction of the cumulative effects model. The information provided on each treated area included the geographic location, area (ha), application date, herbicide prescribed and application rates $\left(\mathrm{L} \cdot \mathrm{ha}^{-1}\right)$. The distribution of the treated areas within the upper Rangitaiki catchment are shown in Figure 1 for Year 1 and 2, and were spatially dispersed over the planted forest area.

Of the 118,345 ha in the Upper Rangitaiki catchment, 4151 ha were treated with herbicides in Year 1. An additional 4696 ha were sprayed in Year 2. These applications amounted to treatments of $3.50 \%$ and $3.97 \%$ of the Upper Rangitaiki River catchment. In Year 1, 86 sites were treated with herbicides (Table 2), starting on 15 September 2012 and finishing on 31 January 2013. In the second year, 108 sites were treated with herbicides (Table 2), starting on 4 September 2013 and ending on 13 December 2014. The treated areas ranged from 3.1 to 172.3 ha in size in Year 1 and 1.6 to 189.4 ha in Year 2 (Table 2). A small area (132.1 ha, 3.2\% of the total treated area) was treated with Viper 90DFTM. Because of the small area treated, and the fact that this was a water-dispersible granular formulation rather than a liquid, these two areas were not incorporated into the cumulative effects analysis. 
Table 2. Upper Rangitaiki catchment herbicide application sites, area ranges, and prescribed application rate summaries, for Year 1 and Year 2.

\begin{tabular}{|c|c|c|c|c|}
\hline Year & Sites (No.) & Herbicide \# & Area Range (ha) & $\begin{array}{c}\text { Prescribed Rate } \\
\left(\mathrm{L} \cdot \mathrm{ha} \mathrm{a}^{-1}\right)\end{array}$ \\
\hline \multirow{4}{*}{1} & 63 & Release $\mathrm{KT}^{\mathrm{TM}}$ & $3.9-172.3$ & $15-17$ \\
\hline & 21 & Gardoprim $^{\mathrm{TM}}$ & $3.1-78.0$ & 15 \\
\hline & 1 & Gardoprim $^{\mathrm{TM}}$ and Viper 90DF & 31.3 & $15 \& 1$ * \\
\hline & 1 & Viper 90DFTM & 100.8 & $1 *$ \\
\hline \multirow{6}{*}{2} & 83 & Release $\mathrm{KT}^{\mathrm{TM}}$ & $2.8-120.5$ & $15-17$ \\
\hline & 7 & Release $\mathrm{KT}^{\mathrm{TM}}$ and Viper 90DF $\mathrm{DF}^{\mathrm{TM}}$ & $2.6-44.3$ & $15-17 \& 1$ * \\
\hline & 2 & Release $\mathrm{KT}^{\mathrm{TM}}$ and Gardoprim ${ }^{\mathrm{TM}}$ & $24.5-53.0$ & 15 \\
\hline & 12 & Gardoprim ${ }^{\mathrm{TM}}$ & $6.6-136.8$ & 15 \\
\hline & 1 & Gardoprim $^{\mathrm{TM}}$ and Viper 90DF & 189.4 & 1 * \\
\hline & 3 & Viper 90DFTM & $1.6-39.8$ & 1 * \\
\hline
\end{tabular}

Notes: * Herbicide applied in $\mathrm{kg} \cdot \mathrm{ha}^{-1}$ as a granule formulation; ${ }^{\#}$ Release $\mathrm{KT}^{\mathrm{TM}}$ (Orion Crop Protection Limited, $435 \mathrm{~g} \cdot \mathrm{L}^{-1}$ terbuthylazine and $65 \mathrm{~g} \cdot \mathrm{L}^{-1}$ hexazinone), Gardoprim ${ }^{\mathrm{TM}}$ (Orion Crop Protection Limited, $500 \mathrm{~g} \cdot \mathrm{L}^{-1}$ terbuthylazine), Viper 90DF"M (Orion Crop Protection Limited, $900 \mathrm{~g} \cdot \mathrm{kg}^{-1}$ ).

\subsubsection{Flow Data}

In the sub-catchment trial site [30], flow velocity measurements taken in Year 2 at the base of the sub-catchment before the stream entered the Rangitaiki River (Figure 2) averaged $2.37 \mathrm{~m} \cdot \mathrm{s}^{-1}$ $(n=9)$. This value was used in the model as the estimated velocity for all other tributaries in the upper Rangitaiki catchment and was used to calculate herbicide residue transit time from applicable treated areas (see model assumptions) along the tributary to the main stem of the Rangitaiki River.

The Rangitaiki flow gauge is located at Murupara (Site No. BOP110015/RO3; Location: NZMG 2832905E). Drought conditions during the time period of the cumulative effects modeling (14 September 2012 to 15 July 2014), particularly during the summer of 2012-2013, affected flows (Figure 3). It was one of the most extreme droughts on record for New Zealand [50], and resulted in a median flow of $13.411 \mathrm{~m}^{3} \cdot \mathrm{s}^{-1}$ during the study from 9 September 2012 to 15 July 2014 . This median flow was considerably lower than the long-term median flow of $21.446 \mathrm{~m}^{3} \cdot \mathrm{s}^{-1}$ (Figure 3).

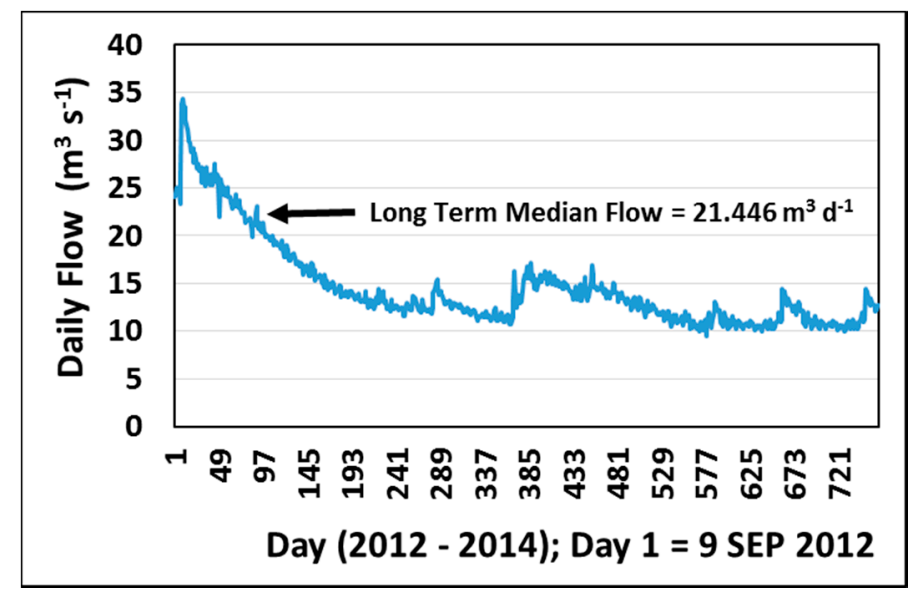

Figure 3. Mean daily streamflow at the Rangitaiki flow gauge, 14 September 2012 to 15 July 2014.

The streamflow velocity at the Rangitaiki flow gauge was rated at $3.6 \mathrm{~km} \cdot \mathrm{h}^{-1}\left(1.0 \mathrm{~m} \cdot \mathrm{s}^{-1}\right)$ (Stan Lodge, Personal Communication, NIWA). That value was then used in the model to calculate herbicide residue transit time along the main stem of the Rangitaiki River. 


\subsubsection{Herbicide Residue Analysis}

Water-sample collection methodology used in the reference catchment (Figure 2) was originally presented by Baillie et al. [30]. The individual water samples collected for herbicide analysis were extracted into dichloromethane using a liquid/liquid separating funnel technique. A $250 \mathrm{~mL}$ of sub-sample was then quantitatively extracted into a final volume of $0.5 \mathrm{~mL}$ of solvent. A deuterated internal standard was used to determine selected compounds. Samples were run on a GC-Agilent $6890 \mathrm{~N}$ MS—Agilent 5975B using a $30 \mathrm{~m} 250 \mu \mathrm{m} \times 0.25 \mu \mathrm{m}$ DB-XLB column using a USA Environmental Protection Agency method [51].

Metabolites of hexazinone were not analyzed since they are very low in toxicity and often at only trace or undetectable levels in forested watersheds [11]. The terbuthylazine metabolite, terbuthylazine desethyl, was at very low, trace, or undetectable levels for most of the study [30]. Because of these factors, metabolites of the two herbicides were not included in the cumulative effects analysis.

\subsection{Model and Assumptions}

The cumulative effects model for the upper Rangitaiki River herbicide application analysis is an Excel [52] spreadsheet model developed by the authors. It involves routing streamflow from individual treated sites along tributary stream channels and into the main stem of the river down to the Rangitaiki flow gauge (Figure 4). Herbicide loading values and streamflow volumes at this site were then used to calculate concentrations for referencing with water quality standards. The modeling time period runs from 9 September 2012 to 4 September 2013 for Year 1 and 4 September 2013 to 7 September 2014 for Year 2.

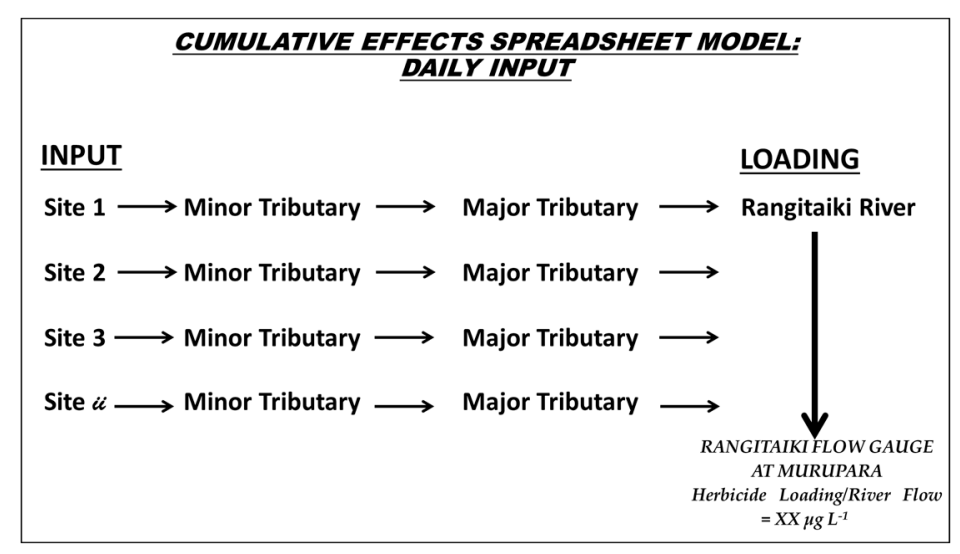

Figure 4. Excel-based herbicide cumulative effects model, Rangitaiki flow gauge at Murupara, New Zealand, 2012-2014.

Firstly, MapToaster Topo@ Version 6 [53] was used to calculate the distance from each treated area to the nearest waterway, as defined on the map, by a straight line method. If a treated area bordered or contained a stream, a $10 \mathrm{~m}$ "no spray" buffer zone (based on Baillie et al. [30]) was subtracted when calculating the distance to nearest waterway. Distances ranged from 0.0 to $4.6 \mathrm{~km}$ in both years. Any treated areas with distances to the nearest waterway of over $0.3 \mathrm{~km}$ were omitted from the cumulative effects analysis. This distance was used because the spray boom configuration on the helicopter, the large droplet size, the retention of a $10 \mathrm{~m}$ "no-spray" buffer around waterways, and low wind speed limits [30], limited the probability of spray drift into streams beyond this distance $[17,26,54]$. Surface runoff could still be a factor beyond $10 \mathrm{~m}$. Volatilization was not considered to be an important movement factor.

For those treated areas $<300 \mathrm{~m}$ from a waterway (77 sites in Year 1 and 95 sites in Year 2), MapToaster Topo@ Version 6 [53] was used to measure the thalweg distance from the entry point to the waterway, downstream to the flow gauge station. The longest distance from any one treated area to the 
Rangitaiki flow gauge was $91 \mathrm{~km}$ and the shortest was $8.7 \mathrm{~km}$. As discussed above, the mean velocities from the sub-catchment trial $\left(2.37 \mathrm{~m} \cdot \mathrm{s}^{-1}\right)$ and the Rangitaiki flow gauge $\left(1 \mathrm{~m} \cdot \mathrm{s}^{-1}\right)$ were applied to the tributaries and main stem of the Rangitaiki River, respectively. Herbicide residue transit times to the Rangitaiki flow gauge were calculated using stream thalweg distances and stream velocities (Table 3). The majority of transit times of herbicide residues from Release $\mathrm{KT}^{\mathrm{TM}}$ and Gardoprim ${ }^{\mathrm{TM}}$ applications in both years, from minor to major tributary, were estimated to be $<0.5 \mathrm{~h}$. Transit times to the Rangitaiki flow gauge were mainly 10 to $15 \mathrm{~h}$ from Release $\mathrm{KT}^{\mathrm{TM}}$ applications and $>15 \mathrm{~h}$ for Gardoprim ${ }^{\mathrm{TM}}$ applications. This difference was mainly due to the location of the Gardoprim ${ }^{\mathrm{TM}}$ applications at more remote locations. Transit times $>24 \mathrm{~h}$ resulted in a one-day delay in input to the Rangitaiki River for the cumulative effects model. In Year 1, herbicide residue releases were delayed one day at six application sites, and in Year 2, five sites incurred a one-day delay in flow input into the Rangitaiki River.

Table 3. Estimated herbicide residue transit times from the sites to the Rangitaiki flow gauge.

\begin{tabular}{ccc}
\hline Herbicide Transit Time to the Rangitaiki Gauge (h) & Year $\mathbf{1}$ & Year $\mathbf{2}$ \\
\cline { 2 - 3 } & No. of Sites & No. of Sites \\
\hline $0-5$ & 8 & 17 \\
$5-10$ & 10 & 19 \\
$10-15$ & 25 & 33 \\
$15-20$ & 22 & 15 \\
$20-25$ & 6 & 5 \\
$25-30$ & 6 & 6 \\
\hline
\end{tabular}

While the authors acknowledge that groundwater processes would have been influencing the aquatic fate of these two herbicides, the cumulative effects modeling did not consider groundwater movement since there was no information available on any groundwater contamination or aquifer transmission rates. However, monitoring of the terrestrial fate of hexazinone and terbuthylazine at the sub-catchment trial site showed minimal movement of both herbicides down the soil profile [16]. Treated areas with local streamflow that became influent into the geologic substrate were also excluded from the analysis since there was no way of accurately tracking water routing and timing.

Data from the sub-catchment herbicide trial was used to provide the model with initial concentrations of herbicide reaching the stream channel for those areas $<0.3 \mathrm{~km}$ from a waterway [30]. The residual decay curves in the stream water developed for both herbicides in Year 1 were used to model downstream dilution of herbicide residues over time as they travelled down the river system to the Rangitaiki flow gauge. Figures 5 and 6 show the decay curves for Year 1 for hexazinone and terbuthylazine, respectively. The model generated for hexazinone was:

$$
y=0.7346 x^{-0.971}
$$

where:

$x=$ time and date

$y=$ hexazinone concentration in $\mu \mathrm{g} \cdot \mathrm{L}^{-1}$. 


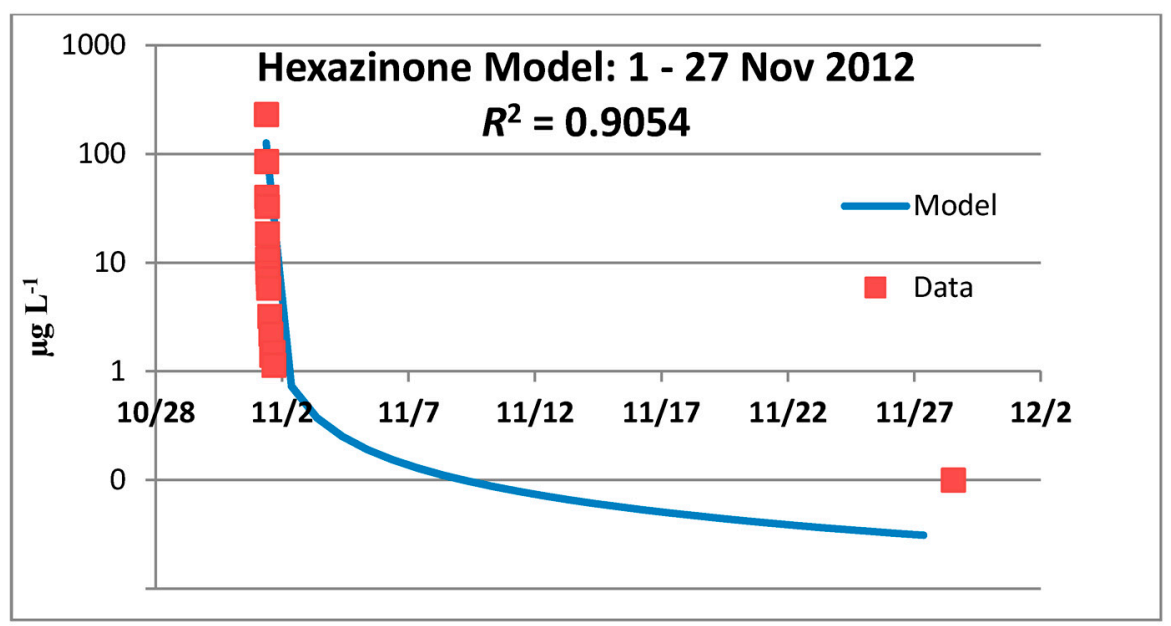

Figure 5. Streamflow hexazinone residue decay curve regression for Year 1 based on data from the sub-catchment trial [30].

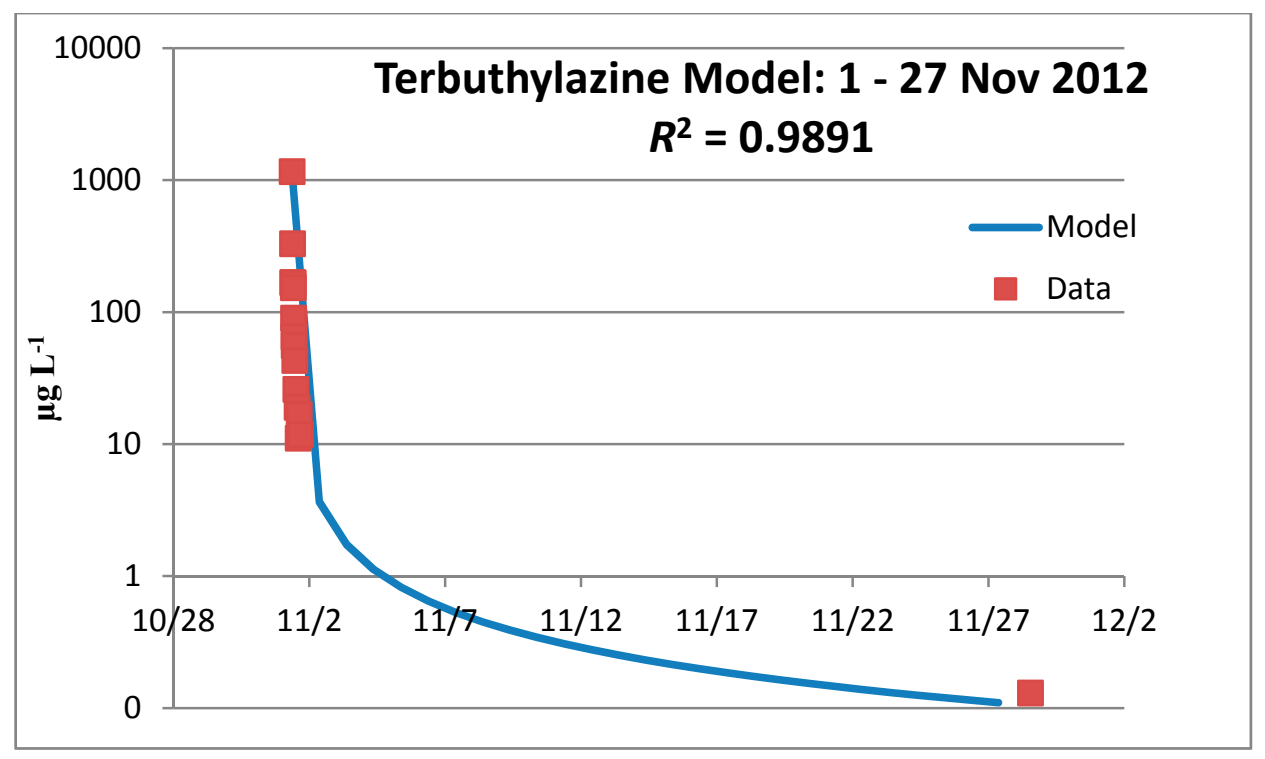

Figure 6. Streamflow terbuthylazine residue decay curve regression for Year 1 based on the data from the sub-catchment trial [30].

The model generated for terbuthylazine was:

$$
y=3.6667 x^{-1.077}
$$

where:

$x=$ time and date

$y=$ terbuthylazine concentration in $\mu \mathrm{g} \cdot \mathrm{L}^{-1}$.

Concentrations on the decay curve were used for interpolations between herbicide residue samplings. Regressions were run for Year 2 hexazinone and terbuthylazine data but they are not presented since the $R^{2}$ values were too low $\left(R^{2}<0.11\right)$ to make the regression curve useful. Detection limits for hexazinone and terbuthylazine in water in the sub-catchment trial ranged from 0.02 to $10.00 \mu \mathrm{g} \cdot \mathrm{L}^{-1}$ depending on the herbicide concentrations in the samples [30]. For modeling purposes, detection levels of $0.02 \mu \mathrm{g} \cdot \mathrm{L}^{-1}$ and $0.04 \mu \mathrm{g} \cdot \mathrm{L}^{-1}$ were used as the water concentrations for hexazinone, and terbuthylazine, respectively, between sampling events and after routine sampling had ceased. 
Instantaneous concentrations were generated within application days based on herbicide residue decay curves from the monitored reference catchment. These concentrations were then averaged to create daily concentration values but they were not flow-weighted.

Safety factors were calculated by dividing the appropriate water quality standards by the daily or instantaneous peak concentrations for each herbicide. The minimum safety factors were calculated by using the peak concentrations (See Tables 4 and 5).

Table 4. Hexazinone toxicological parameters and modeled safety factors for Years 1 and 2.

\begin{tabular}{|c|c|c|c|c|c|}
\hline \multirow{2}{*}{ Parameter ${ }^{\circledR}$} & \multirow{2}{*}{ Life Form } & \multirow{2}{*}{ Standard ${ }^{\circledR}$} & \multirow{2}{*}{ Ingestion/Exposure } & \multirow{2}{*}{$\begin{array}{c}\text { Safety Factor } \\
\text { Year } 1\end{array}$} & \multirow{2}{*}{$\begin{array}{c}\text { Safety Factor } \\
\text { Year } 2\end{array}$} \\
\hline & & & & & \\
\hline Human ADI \# & $50 \mathrm{~kg}$ Adult & $0.25 \mathrm{mg} \cdot$ day $^{-1}$ & $4{\mathrm{~L} \cdot \mathrm{day}^{-1}}^{-1}$ & $>5410$ & $>1886$ \\
\hline Human ADI ${ }^{\#}$ & $50 \mathrm{~kg}$ Adult & $0.25 \mathrm{mg} \cdot \mathrm{day}^{-1}$ & $1.0 \mathrm{~m}^{3} \cdot \mathrm{day}^{-1}$ & $>22$ & $>7$ \\
\hline $\begin{array}{l}\text { New Zealand Drinking } \\
\text { Water Standard }\end{array}$ & - & $400 \mu \mathrm{g} \cdot \mathrm{L}^{-1}$ & $\begin{array}{l}\text { Mean Daily } \\
\text { Concentration }\end{array}$ & $>34,623$ & $>12,074$ \\
\hline $\begin{array}{l}\text { New Zealand Drinking } \\
\text { Water Standard }\end{array}$ & - & $400 \mu \mathrm{g} \cdot \mathrm{L}^{-1}$ & $\begin{array}{l}\text { Instantaneous } \\
\text { Concentration }\end{array}$ & $>1861$ & $>4000$ \\
\hline Daphnia LC50 & Adult & $>21,000 \mu \mathrm{g} \cdot \mathrm{L}^{-1}$ & $48 \mathrm{~h}$ & $>117,087$ & $>4.420 \times 10^{6}$ \\
\hline Oncorhynchus mykiss LC50 & Adult & $320,000 \mu \mathrm{g} \cdot \mathrm{L}^{-1}$ & $96 \mathrm{~h}$ & $>1.784 \times 10^{6}$ & $>3.200 \times 10^{6}$ \\
\hline
\end{tabular}

Table 5. Terbuthylazine toxicological parameters and safety factors.

\begin{tabular}{|c|c|c|c|c|c|}
\hline \multirow{2}{*}{ Parameter ${ }^{\circledR}$} & \multirow{2}{*}{ Life Form } & \multirow{2}{*}{ Standard ${ }^{\circledR}$} & \multirow{2}{*}{ Ingestion/Exposure \# } & \multirow{2}{*}{$\begin{array}{c}\text { Safety Factor } \\
\text { Year } 1\end{array}$} & \multirow{2}{*}{$\begin{array}{c}\text { Safety Factor } \\
\text { Year } 2\end{array}$} \\
\hline & & & & & \\
\hline Human ADI \# & $50 \mathrm{~kg}$ Adult & $0.20 \mathrm{mg} \cdot$ day $^{-1}$ & $4{\mathrm{~L} \cdot \mathrm{day}^{-1}}^{-1}$ & $>25,986$ & $>1711$ \\
\hline Human ADI \# & $50 \mathrm{~kg}$ Adult & $0.20 \mathrm{mg} \cdot \mathrm{day}^{-1}$ & $1.0 \mathrm{~m}^{3} \cdot$ day $^{-1}$ & $>104$ & $>7$ \\
\hline $\begin{array}{c}\text { New Zealand Drinking } \\
\text { Water Standard }\end{array}$ & -0 & $8 \mu \mathrm{g} \cdot \mathrm{L}^{-1}$ & $\begin{array}{l}\text { Mean Daily } \\
\text { Concentration }\end{array}$ & $>119$ & $>8$ \\
\hline $\begin{array}{c}\text { New Zealand Drinking } \\
\text { Water Standard }\end{array}$ & - & $8 \mu \mathrm{g} \cdot \mathrm{L}^{-1}$ & $\begin{array}{l}\text { Instantaneous } \\
\text { Concentration }\end{array}$ & $>7$ & $>80$ \\
\hline Daphnia LC50 & Adult & $442,000 \mu \mathrm{g} \cdot \mathrm{L}^{-1}$ & $48 \mathrm{~h}$ & $>362,510$ & $>216,234$ \\
\hline Oncorhynchus mykiss LC50 & Adult & $3800 \mu \mathrm{g} \cdot \mathrm{L}^{-1}$ & $96 \mathrm{~h}$ & $>3117$ & $>1859$ \\
\hline
\end{tabular}

Notes: ${ }^{\#}$ ADI = Acceptable Daily Intake for the life of an individual [53,54]; ${ }^{@}$ Parameters and concentrations from [15].

No hydrolytic, photolytic, or microbial degradation data of either herbicide were included in the analysis since no on-site data were available $[13,30]$. The authors acknowledge that degradation processes would have influenced these results to a limited extent.

\subsection{Herbicide Degradation}

The presence of sunlight and water are factors in the degradation of both herbicides. Hexazinone is generally stable in water and shows little tendency to hydrolyze over the short term $[23,25,55-59]$. In water, under lighted conditions, hexazinone is slowly degraded to metabolite A by hydroxylation, and to metabolites B and H by demethylation [60]. Degradation of terbuthylazine in natural water depends on the presence of sediments and biological activity [56,57].

Studies of river water and pond water have indicated variable half-lives ranging from $>1$ year to 3 months to $>1$ month. Other studies have found that, for very high sunlight intensities (full midday sunlight), the terbuthylazine half-life was $39 \mathrm{~h}[61,62]$. These degradation processes were not considered in the cumulative effects analysis since no local data were available to corroborate results of other studies for the Rangitaiki River. The authors acknowledge that degradation processes would have influenced these results to a limited extent. 


\section{Results}

\subsection{The Year 1 and Year 2 Spatial and Time Distributions of Herbicide Application}

The herbicide application sites were reasonably well distributed throughout the planted forest portion of the upper Rangitaiki River catchment (Figure 2). Some crowding of treated areas was observed within and between years (Table 6). There were 17 instances of time crowding in Year 1 when two to nine areas were treated on the same day. On eight of those dates, space crowding occurred when two to three adjacent sites were treated. In Year 2, there was time crowding on 22 days when two or more sites were sprayed, with a daily maximum of nine sites occurring on four occasions. Space crowding in Year 2 was more common with 15 days having one or more instances of this type of cumulative effect. On 10 October, only one site of the ten treated was not space crowded. Space crowding can result in more herbicide residues entering common channels at the same or similar times, adding time crowding to the effect. Even with greater time intervals between applications, the residue decay curves are additive. Thus the spacing crowding effect creates higher herbicide concentrations in streamflow.

Table 6. Occurrence of time and space crowding from herbicide applications in the upper Rangitaiki catchment, 2013-2014.

\begin{tabular}{ccccc}
\hline \multirow{2}{*}{ Year } & Applications & $\begin{array}{c}\text { Herbicide } \\
\text { Applied }\end{array}$ & $\begin{array}{c}\text { Time Crowding } \\
\text { Occurrence }\end{array}$ & $\begin{array}{c}\text { Space Crowding } \\
\text { Occurrence }\end{array}$ \\
\cline { 2 - 5 } & Calendar & Days & Days & Days \\
\hline $1(2013)$ & 13 September-24 January & 26 & 17 & 8 \\
$2(2014)$ & 4 September-13 December & 26 & 22 & 15 \\
\hline
\end{tabular}

\subsection{Hexazinone Cumulative Effects Analysis}

\subsubsection{Year 1}

The daily average hexazinone residues in Year 1 modeled in the cumulative effects analysis for the upper Rangitaiki River are displayed in Figure 7. Although the model generated numerous peaks in hexazinone, none of them would be detectable in water samples. The detection limit with current technology is $0.020 \mu \mathrm{g} \cdot \mathrm{L}^{-1}$ (solid line, Figure 7). The highest peaks in simulated residue flow occurred in late October and early November, 2012, when there was some time and space crowding and a large number of applications (20 of 64). The six-peak daily hexazinone concentrations over $0.005 \mu \mathrm{g} \cdot \mathrm{L}^{-1}$ in the Rangitaiki cumulative effects analysis were at undetectable levels between $0.012 \mu \mathrm{g} \cdot \mathrm{L}^{-1}$ (11 November 2012) and $0.005 \mu \mathrm{g} \cdot \mathrm{L}^{-1}$ (9 and 17 November 2012). The single peak at Day 217 (17 April 2013; Figure 7) just over $0.004 \mu \mathrm{g} \cdot \mathrm{L}^{-1}$ was due to the simulation of a one-day storm runoff pulse.

Instantaneous hexazinone peak concentrations above the detection level of $0.020 \mu \mathrm{g} \cdot \mathrm{L}^{-1}$, were simulated to occur 38 times on 22 days between 15 September 2012 (Day 2) and 19 December 2013 (Day 463, Figure 8). Peaks 1-3 lasted 98 min with four successive samples containing hexazinone residues that would be detectable. Peak number 4 was characterized by detectable residues that persisted for $83 \mathrm{~min}$ (Figure 8). Most of the other peaks above the hexazinone detection level persisted for only $15 \mathrm{~min}$ in the simulation. For peak number 1 on 15 November (Day 63), the simulated maximum hexazinone concentration was $0.179 \mu \mathrm{g} \cdot \mathrm{L}^{-1}$ that declined rapidly to $<0.067 \mu \mathrm{g} \cdot \mathrm{L}^{-1}$ over the next 45 min. Instantaneous peak concentrations on Day 41 (24 October 2012), Day 49 (1 November 2012), and Day 40 (23 October 2012) were $0.161,0.138$, and $0.128 \mu \mathrm{g} \cdot \mathrm{L}^{-1}$, respectively (Points $2-4$, Figure 8). All other detectable peaks (21) were simulated to be less than $0.10 \mu \mathrm{g} \cdot \mathrm{L}^{-1}$. 


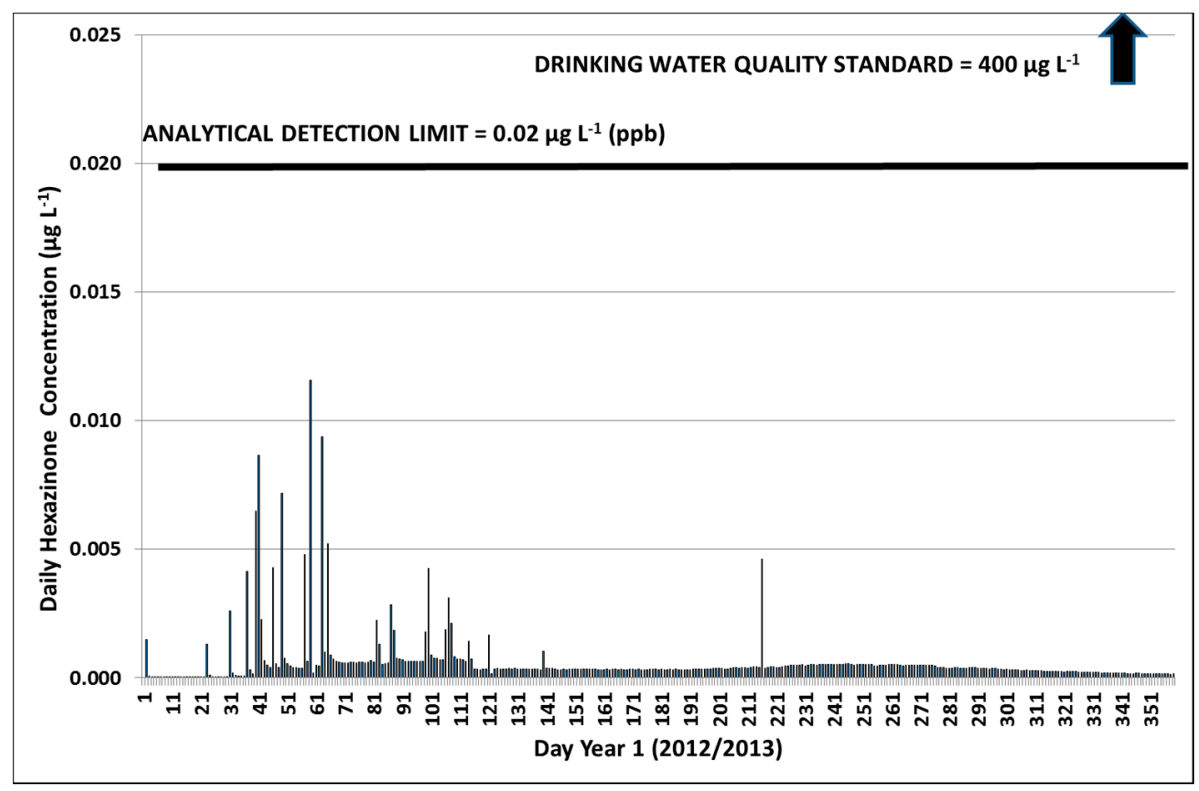

Figure 7. Year 1-modeled daily average concentrations of hexazinone in the Rangitaiki River at the Rangitaiki flow gauge.

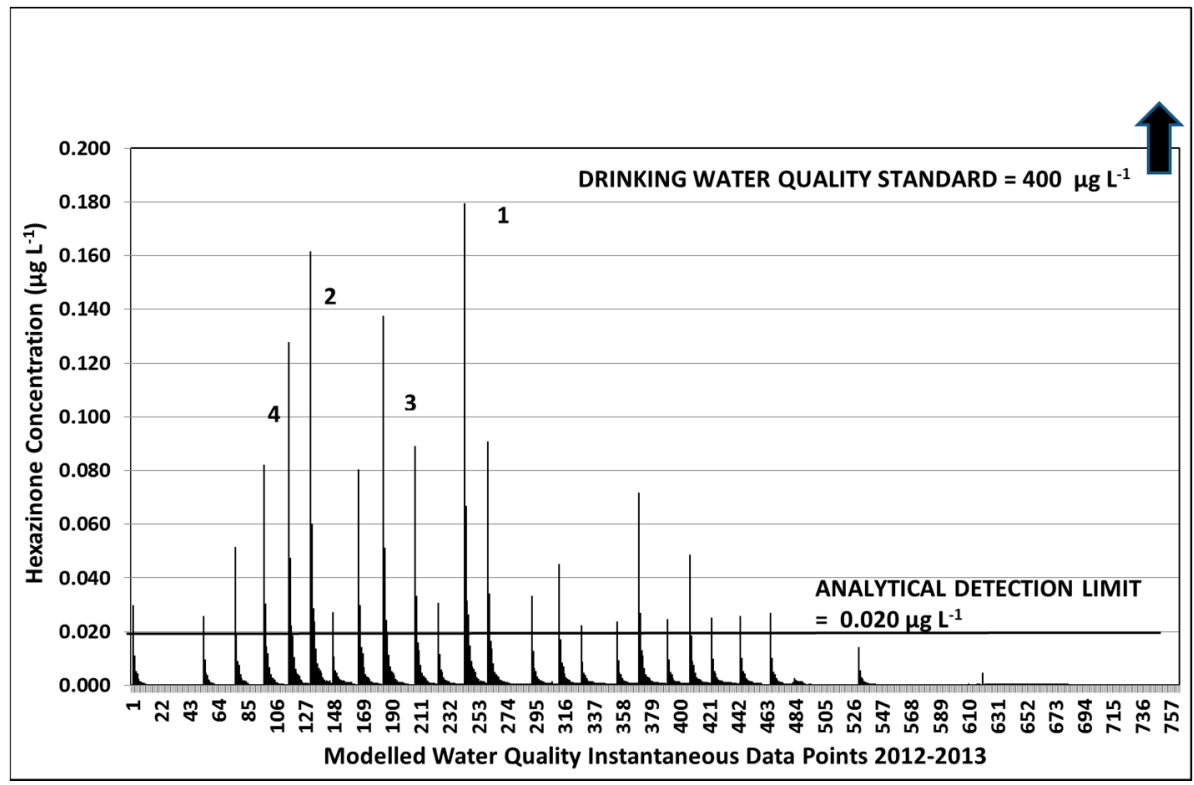

Figure 8. Year 1-modeled instantaneous concentrations of hexazinone in the Rangitaiki River at the Rangitaiki flow gauge.

Hexazinone daily mass loadings in the Rangitaiki River in Year 1 at the flow gauging station are shown in Figure 9. The peak daily loading was $22,868 \mathrm{mg}$ on Day 59 (11 November 2012) after nine sites were treated in 14 days, including the reference catchment. Of the $3601 \mathrm{~kg}$ of hexazinone applied to the treated areas, the cumulative amount of hexazinone in streamflow for the entire Upper Rangitaiki Basin, as simulated at the Rangitaiki flow gauge, was $0.366 \mathrm{~kg}$, or $0.010 \%$ of the applied chemical. 


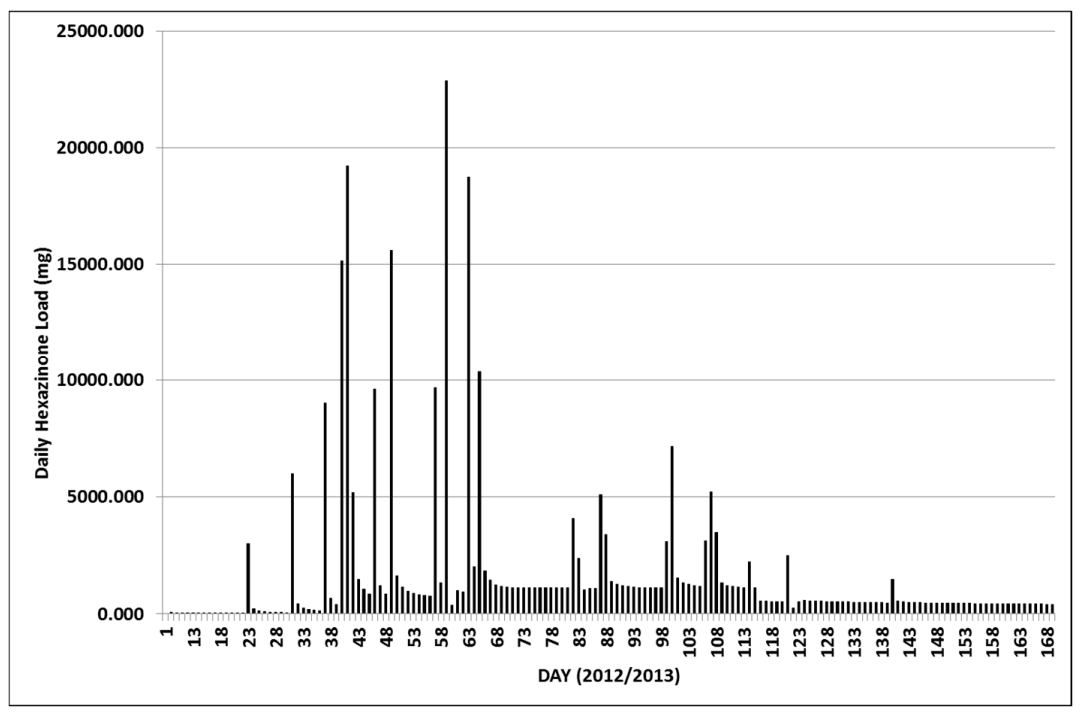

Figure 9. Year 1-modeled daily loadings in $\mathrm{mg}$ of hexazinone in the Rangitaiki River at the Rangitaiki flow gauge.

\subsubsection{Year 2}

The daily average hexazinone residues in Year 2 modeled in the cumulative effects analysis for the Rangitaiki River at the flow gauge station are shown in Figure 10. Similar to Year 1, the model generated numerous peaks in hexazinone. However, only one daily average peak (6 November 2013, Day $66 ; 0.033 \mu \mathrm{g} \cdot \mathrm{L}^{-1}$ ) was simulated to produce a detectable concentration in water samples, at the detection limit of $0.020 \mu \mathrm{g} \cdot \mathrm{L}^{-1}$ (solid line, Figure 10). The highest peaks in simulated residue movement occurred on 1 (Day 62) and 6 November (Day 66), and 12 December, 2013 (Day 102), when there was some time and space crowding and a large number of applications (19 of 94). The two-peak daily average hexazinone concentrations over $0.010 \mu \mathrm{g} \cdot \mathrm{L}^{-1}$ in the Year 2 cumulative effects analysis were associated with storm events and ranged from 0.033 to $0.016 \mu \mathrm{g} \cdot \mathrm{L}^{-1}$. The single peak at Day 229 of just over $0.004 \mu \mathrm{g} \cdot \mathrm{L}^{-1}$ was due to the simulation of a one-day storm runoff pulse.

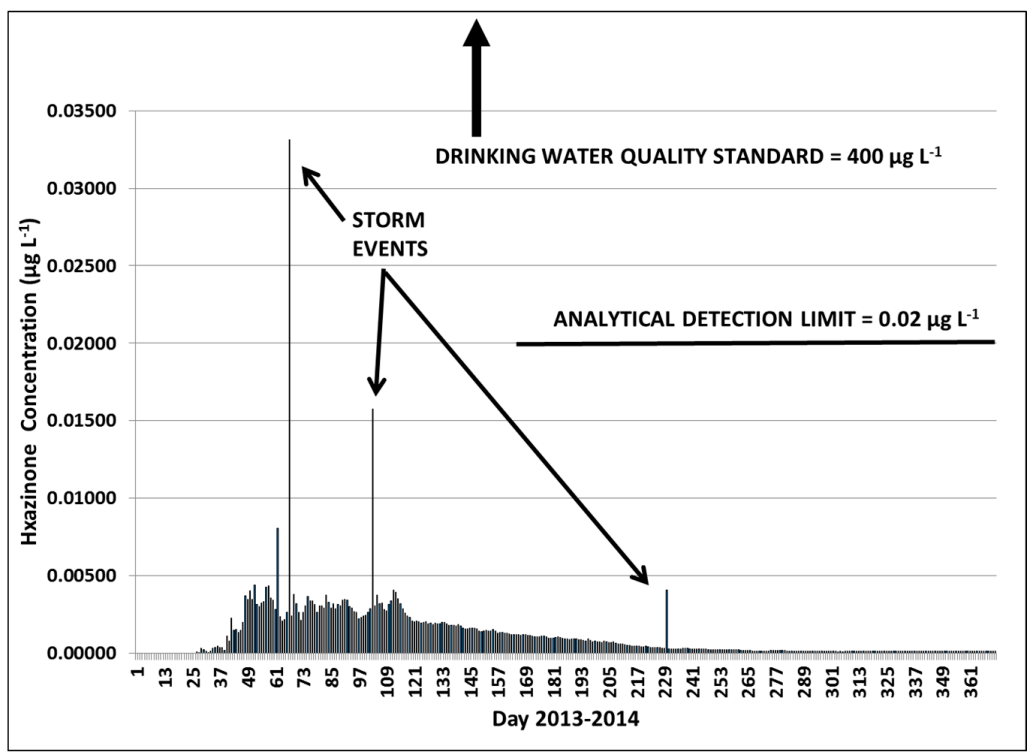

Figure 10. Year 2-modeled daily average concentrations of hexazinone in the Rangitaiki River at the Rangitaiki flow gauge. 
Four instantaneous hexazinone peak concentrations above the detection level $\left(0.020 \mu \mathrm{g} \cdot \mathrm{L}^{-1}\right)$ was simulated to occur on one day 6 November (Day 64) during a storm event (Figure 11). The respective peak concentrations were $0.047,0.077,0.084$, and $0.047 \mu \mathrm{g} \cdot \mathrm{L}^{-1}$. Another storm event on 12 December 2013 (Day 99) had a peak modeled instantaneous concentrations of $0.038,0.025,0.032$, and $0.039 \mu \mathrm{g} \cdot \mathrm{L}^{-1}$. A smaller peak of $0.008 \mu \mathrm{g} \cdot \mathrm{L}^{-1}$ occurred on Day 59 , five days before the main peak concentration on Day 64. All other modeled instantaneous residue peaks were less than $0.008 \mu \mathrm{g} \cdot \mathrm{L}^{-1}$.

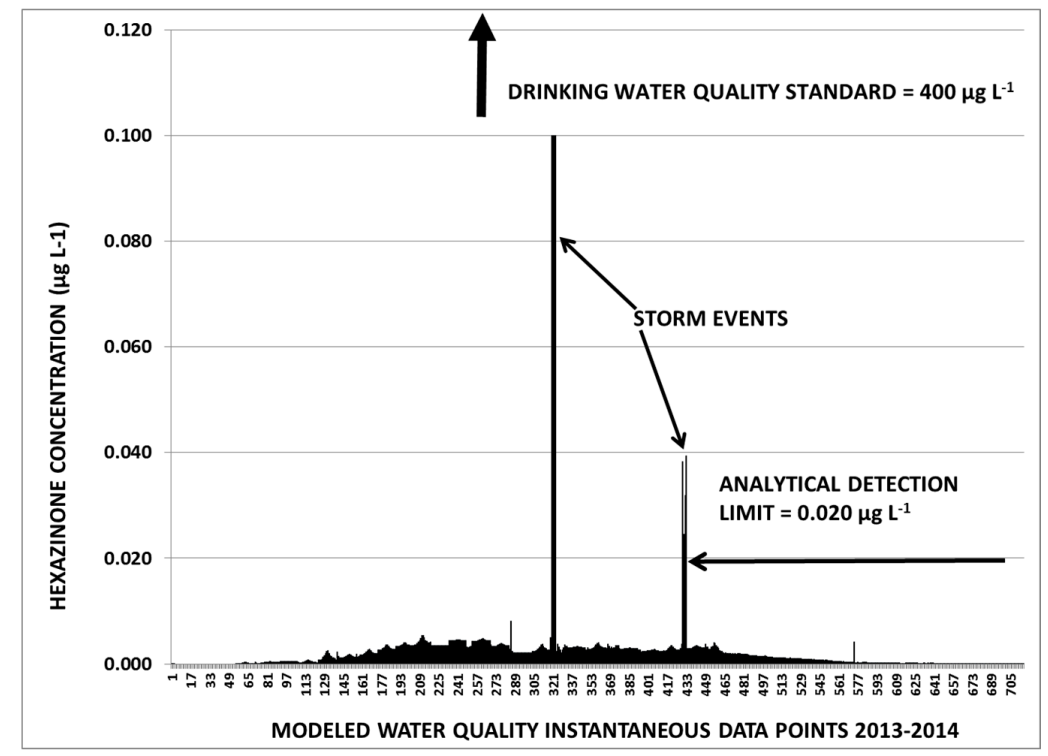

Figure 11. Year 2-modeled instantaneous concentrations of hexazinone in the Rangitaiki River at the Rangitaiki flow gauge.

Hexazinone daily mass loadings in Year 2 at the Rangitaiki flow gauge on the Rangitaiki River are shown in Figure 12. Of the $3369 \mathrm{~kg}$ of hexazinone applied to the treated areas in Year 2, the cumulative amount of the herbicide in streamflow for the entire Upper Rangitaiki Basin, as modeled at the Rangitaiki flow gauge, was $0.523 \mathrm{~kg}$, or $0.016 \%$ of the applied chemical.

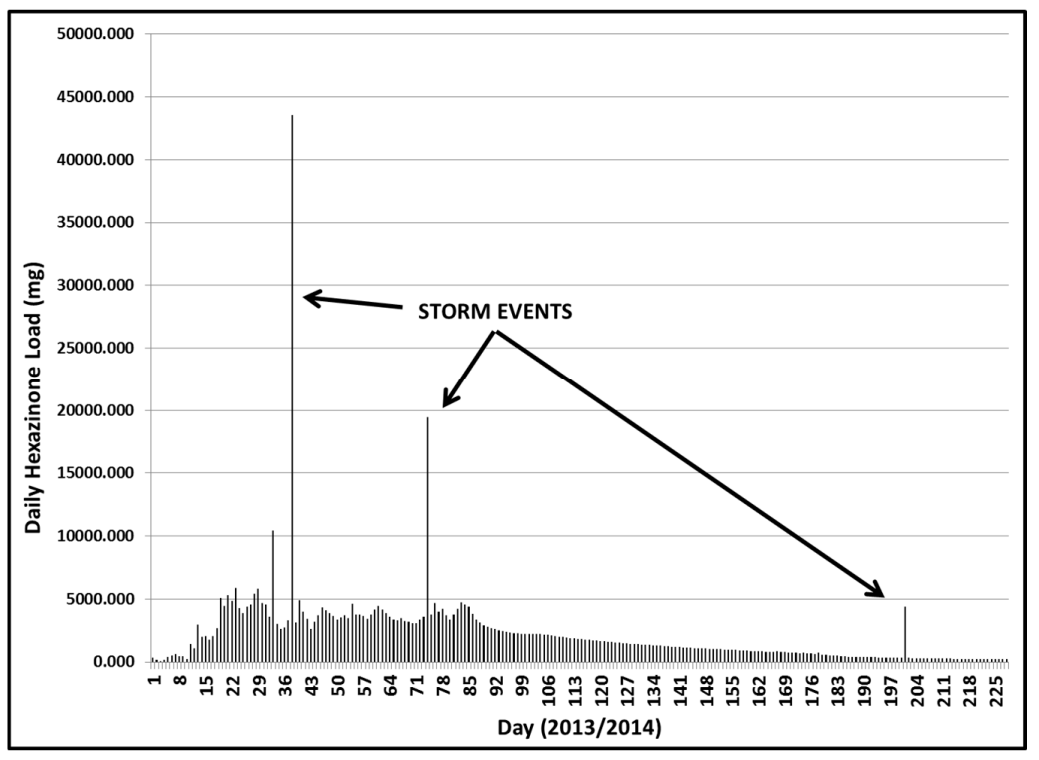

Figure 12. Year 2-daily loadings of hexazinone in the Rangitaiki River at the Rangitaiki flow gauge. 


\subsubsection{Hexazinone Safety Factors}

None of the daily average or instantaneous hexazinone peak concentrations in both Year 1 and 2 were of any toxicological significance (Table 4). In Year 1, the safety factors were large, ranging from $>5407$ for human Acceptable Daily Intake of $4 \mathrm{~L} \cdot$ day $^{-1}$ to 97,690 for Daphnia spp. LC50 (lethal concentration killing $50 \%$ of individuals in $48 \mathrm{~h}$ ). The rainbow trout LC50 safety factors were all in excess of $1.489 \times 10^{6}$. The lowest safety factor for the NZ drinking water standard was 1861 based on the model's simulation of the instantaneous concentrations (Figure 8), and a safety factor of 34,623 for the daily average concentration (Figure 7). The other low safety factor (22) was based on improbable ingestion of $1.0 \mathrm{~m}^{3} \cdot$ day $^{-1}$ of water.

In Year 2, safety factors ranged from $>1886$ for human Acceptable Daily Intake of $4 \mathrm{~L} \cdot$ day $^{-1}$ to $4.420 \times 10^{6}$ for Daphnia spp. LC50. The rainbow trout LC50 safety factors were all in excess of $3200 \times 10^{6}$. The lowest safety factor for the NZ drinking water standard was 4000 based on the model's simulation of the instantaneous concentrations (Figure 11), and a safety factor of $>12,074$ for the daily average concentration (Figure 10). The other low safety factor (7) was based on improbable ingestion of $1.0 \mathrm{~m}^{3} \cdot \mathrm{day}^{-1}$. Thus the risk of hexazinone to human health and safety and aquatic organisms, based on residues estimated for the Rangitaiki River at the flow gauge station in both years, was essentially zero.

\subsection{Terbuthylazine Cumulative Effects Analysis}

\subsubsection{Year 1}

The daily average terbuthylazine residues in Year 1 modeled in the cumulative effects analysis for the Rangitaiki River at the flow gauge are displayed in Figure 13. The model generated four daily peaks of terbuthylazine above the $0.040 \mu \mathrm{g} \cdot \mathrm{L}^{-1}$ (solid line, Figure 13), but none were above the New Zealand drinking water standard $\left(8 \mu \mathrm{g} \cdot \mathrm{L}^{-1}\right)$. The highest peaks in simulated residue movement occurred in late October and early November 2012, when there was some time and space crowding and a large number of applications (25 of 77$)$.

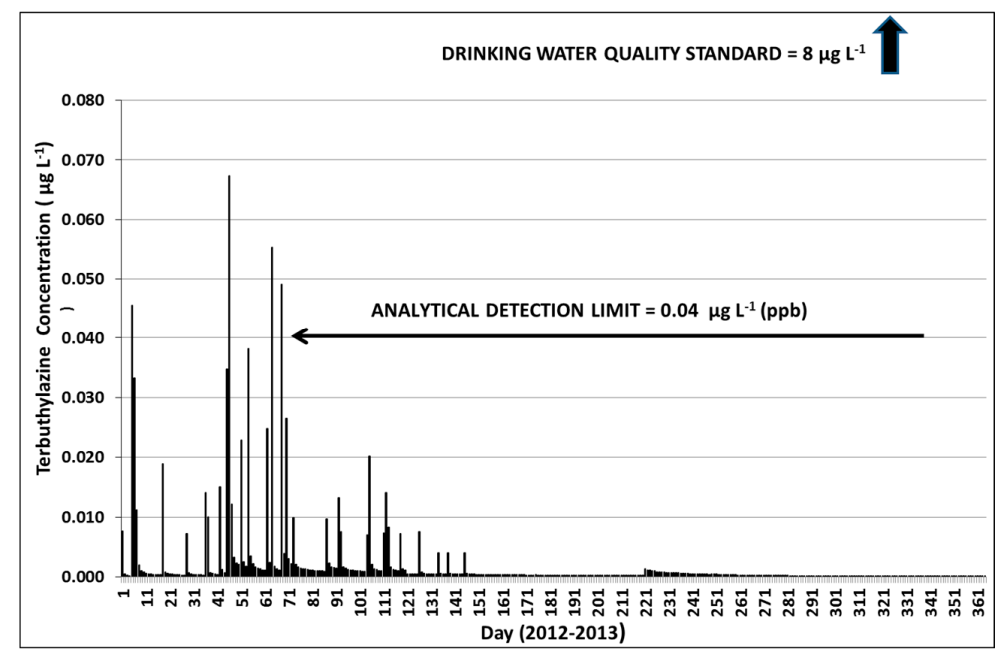

Figure 13. Year 1-modeled daily average concentrations of terbuthylazine in the Rangitaiki River at the Rangitaiki flow gauge.

The nine highest peaks in the daily average terbuthylazine concentrations in the Rangitaiki cumulative effects analysis were between 0.025 and $0.067 \mu \mathrm{g} \cdot \mathrm{L}^{-1}$. The four concentration peaks above $0.040 \mu \mathrm{g} \cdot \mathrm{L}^{-1}$ ranged from 0.046 to $0.067 \mu \mathrm{g} \cdot \mathrm{L}^{-1}$. Exceedance of the terbuthylazine drinking water quality standard was never at risk since it is 119 times higher than the modeled peak. 
Instantaneous terbuthylazine peak concentrations above the detection level $\left(0.040 \mu \mathrm{g} \cdot \mathrm{L}^{-1}\right)$ were simulated to occur on 31 days between 9 September 2012 and 31 January 2013 (Figure 14). Peaks 1-3 lasted 98 min with eight to nine successive samples containing terbuthylazine residues that would be detectable. Peak number 1 was characterized by detectable residues that persisted for much of the day. Most of the other peaks above the terbuthylazine detection level persisted for variable time periods in the simulation. For peak number 1 on 24 October 2012 (Day 201), the simulated maximum instantaneous terbuthylazine concentration was $1.219 \mu \mathrm{g} \cdot \mathrm{L}^{-1}$ that dropped to $0.349,0.179$ and $0.177 \mu \mathrm{g} \cdot \mathrm{L}^{-1}$ over the next $45 \mathrm{~min}$. The four other residue spikes on 15 November, 13 September, 1 November, and 23 October were $0.903,0.854,0.694$ and $0.644 \mu \mathrm{g} \cdot \mathrm{L}^{-1}$, respectively. All other detectable residue peaks were simulated to be less than $0.600 \mu \mathrm{g} \cdot \mathrm{L}^{-1}$.

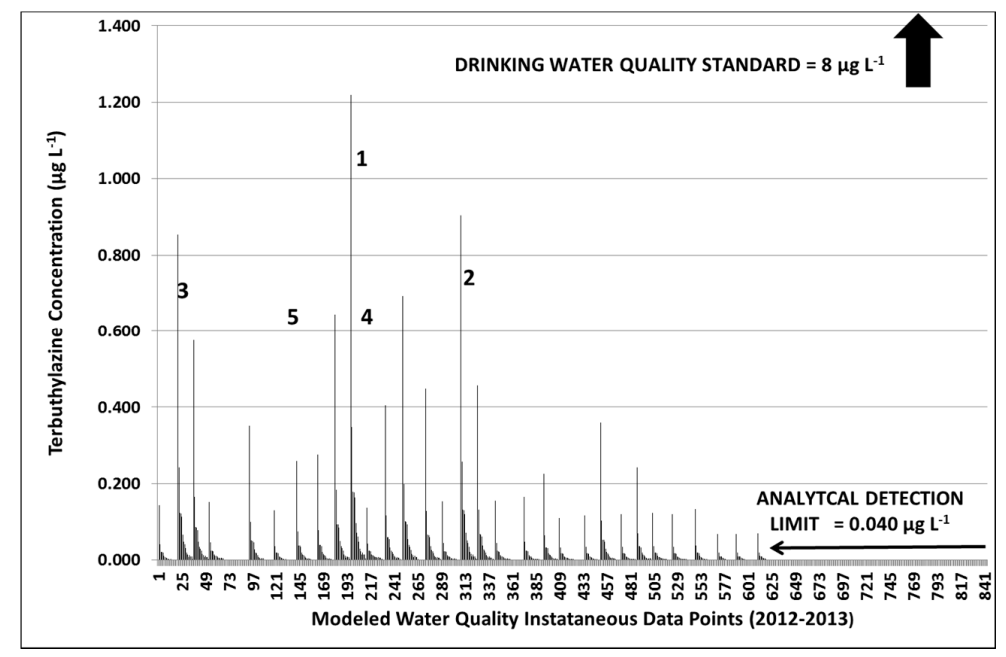

Figure 14. Year 1-modeled instantaneous concentrations of terbuthylazine in the Rangitaiki River at the Rangitaiki flow gauge.

Terbuthylazine daily loadings for Year 1 in the Rangitaiki River at the Rangitaiki flow gauge are shown in Figure 15. Of the $29,333 \mathrm{~kg}$ of terbuthylazine applied to the treated areas in the upper Rangitaiki catchment, the cumulative amount of the herbicide loss for the entire Upper Rangitaiki Basin, as modeled at the flow gauge was $1.563 \mathrm{~kg}$, or $0.005 \%$ of the applied chemical.

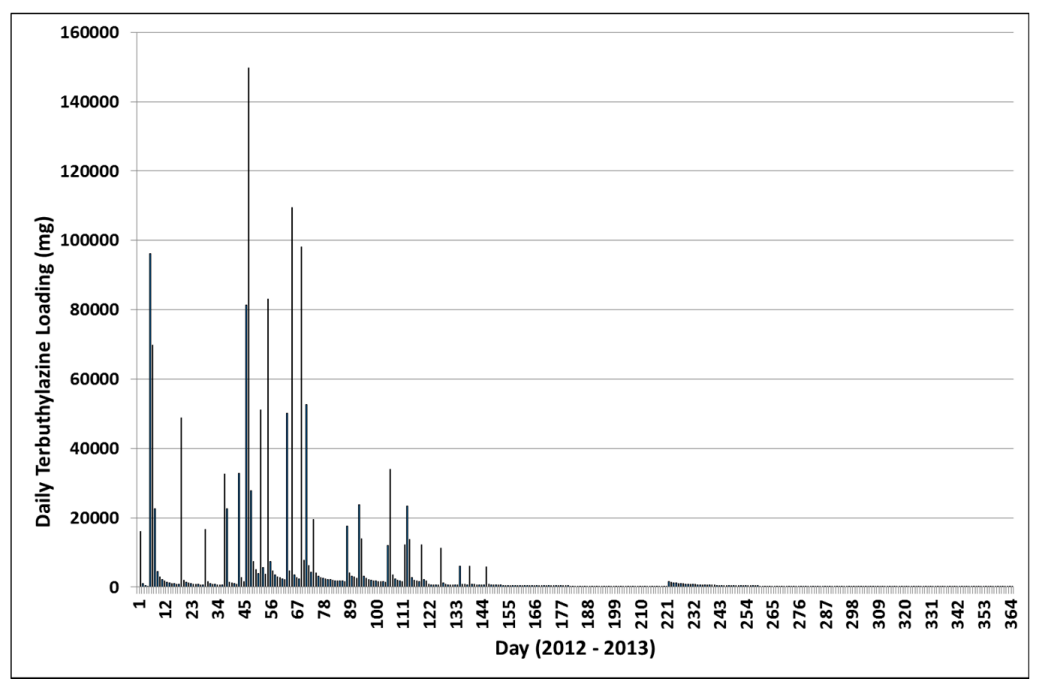

Figure 15. Year 1-daily loadings of terbuthylazine in the Rangitaiki River at the Rangitaiki flow gauge. 


\subsubsection{Year 2}

The daily average terbuthylazine residues in Year 2 modeled in the cumulative effects analysis for the Rangitaiki River at the flow gauge are shown in Figure 16. The model generated a number of peaks less than the detection limit. The two highest were $0.038 \mu \mathrm{g} \cdot \mathrm{L}^{-1}$ on 6 November 2013 (Day 67) and $0.036 \mu \mathrm{g} \cdot \mathrm{L}^{-1}$ (Day 103) on 12 December, associated with storm events.

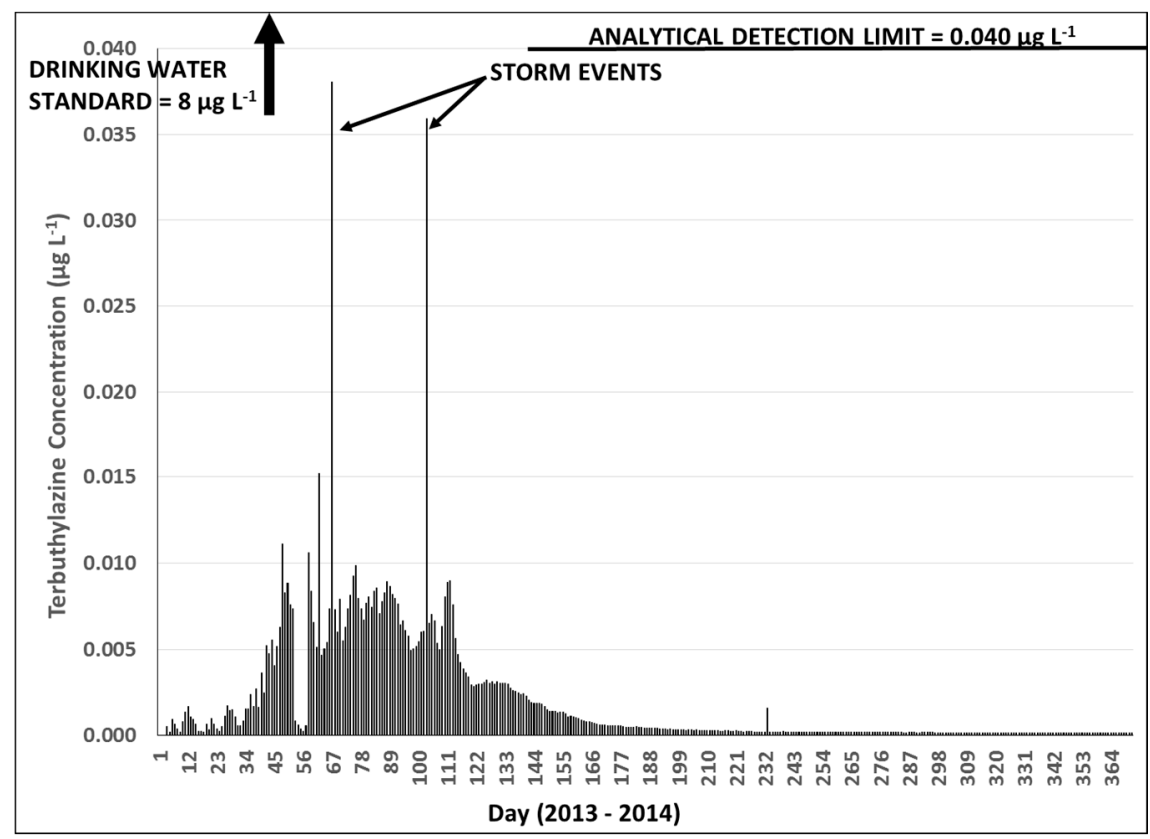

Figure 16. Year 2-modeled daily average concentrations of terbuthylazine in the Rangitaiki River at the Rangitaiki flow gauge.

There were two days where four instantaneous peaks in terbuthylazine were above the $0.040 \mu \mathrm{g} \cdot \mathrm{L}^{-1}$ detection limit (Figure 17). The first daily peak consisted of terbuthylazine instantaneous peaks of 2.044, 0.263, 0.307, and $1.898 \mu \mathrm{g} \cdot \mathrm{L}^{-1}$ on 6 November 2013 (Day 67). Figure 17 shows them only as $0.100 \mu \mathrm{g} \cdot \mathrm{L}^{-1}$ for graphing purposes. The second storm peak on 12 December 2013 (Day 103) is also a set of four with concentrations of $0.091,0.059,0.079$, and $0.092 \mu \mathrm{g} \cdot \mathrm{L}^{-1}$. These peaks in simulated residue movement were associated with storm events but there was some time and space crowding with seven herbicide applications one or two days prior to the storms.

Terbuthylazine daily loadings for Year 2 in the Rangitaiki River at the flow gauge are shown in Figure 18. The peak loading of $1.344 \times 10^{6} \mathrm{mg}(1.344 \mathrm{~kg})$ occurred on 6 November 3013 (Day 67). Of the $34,897 \mathrm{~kg}$ of terbuthylazine applied to the treated areas in the upper Rangitaiki catchment in Year 2, the cumulative loss of the herbicide for the entire Upper Rangitaiki catchment, as simulated at the flow gauge on the Rangitaiki River, was $2.267 \mathrm{~kg}$, or $0.006 \%$ of the applied chemical. 


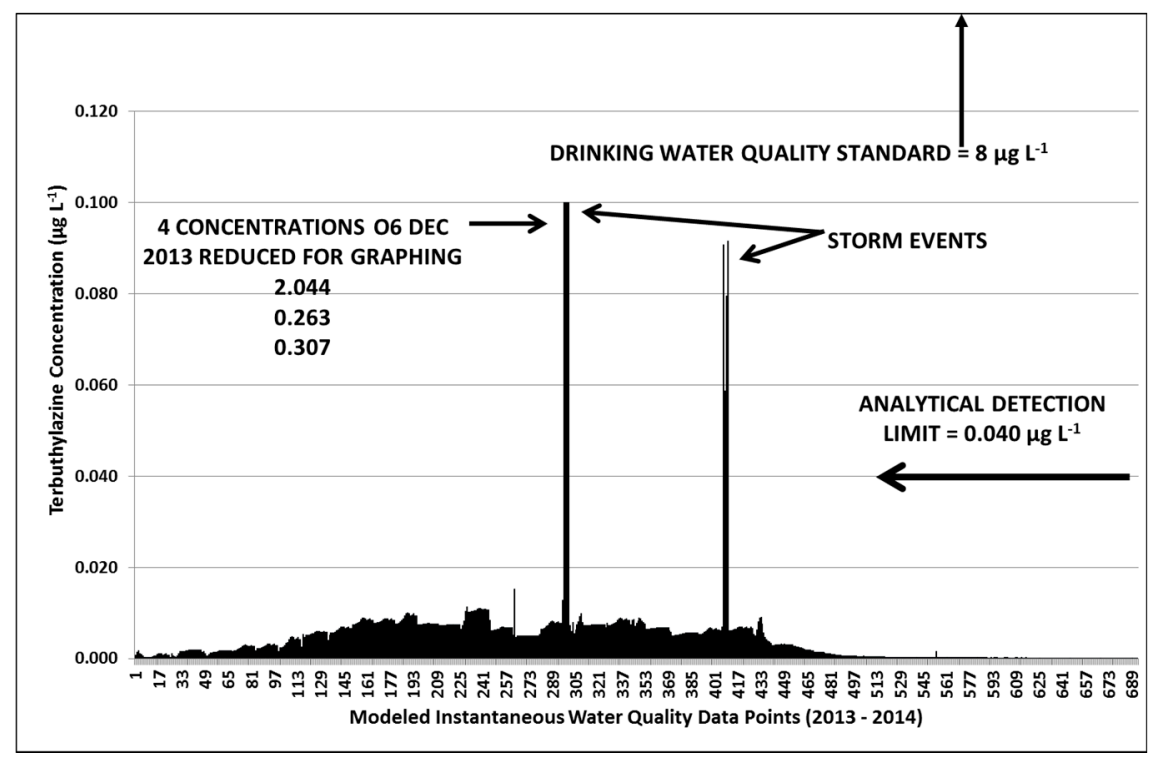

Figure 17. Year 2-modeled instantaneous concentrations of terbuthylazine in the Rangitaiki River at the Rangitaiki flow gauge.

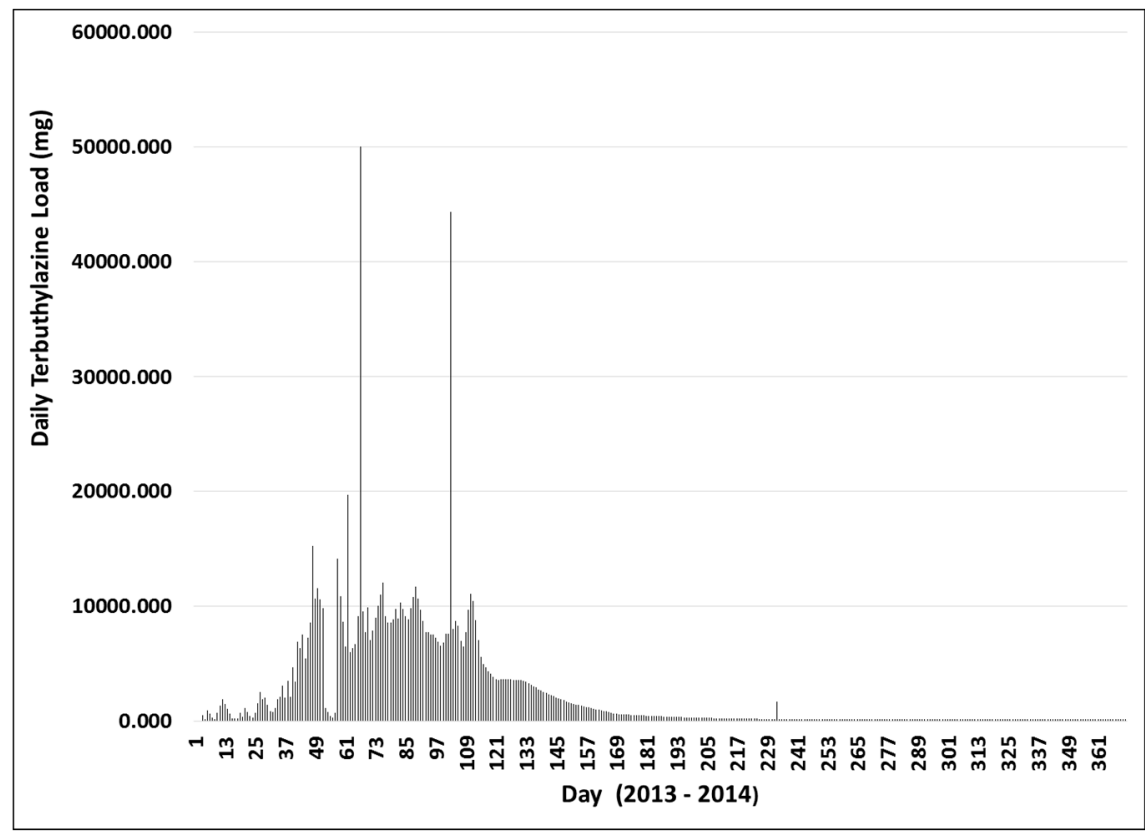

Figure 18. Year 2-daily loadings of terbuthylazine at the Rangitaiki flow gauge.

\subsubsection{Terbuthylazine Safety Factors}

None of the modeled daily average or instantaneous terbuthylazine peak concentrations in either Year 1 or Year 2 was of any toxicological significance (Table 5). The safety factors in Year 1 were large, ranging from $>25,986$ for human Acceptable Daily Intake of $4 \mathrm{~L} \cdot$ day $^{-1}$ to $>362,510$ for Daphnia spp. LC50. The rainbow trout LC50 safety factors were all in excess of 3117. The lowest safety factor for the NZ drinking water standard (same as the World Health Organization standard for terbuthylazine [63]) was 7 , based on simulated instantaneous concentrations (Figure 14) and $>119$ for the daily average concentration(Figure 13). The other low safety factor (104) was based on improbable ingestion of $1.0 \mathrm{~m}^{3} \cdot$ day $^{-1}$ of water. 
The safety factors were also large in Year 2, ranging from $>4.7 \times 10^{6}$ for human Acceptable Daily Intake of $4 \mathrm{~L} \cdot \mathrm{day}^{-1}$ to $>216,234$ for Daphnia spp. LC50. The rainbow trout LC50 safety factors were all in excess of 1859. The lowest safety factor for the NZ drinking water standard was $>80$, based on simulated instantaneous concentrations (Figure 17), and $>8$ for the daily average concentration (Figure 16). The other low safety factor (7) was based on improbable ingestion of $1.0 \mathrm{~m}^{3} \cdot \mathrm{day}^{-1}$. The risk to human health and safety, based on terbuthylazine residues estimated for the Rangitaiki River at the flow gauge for both years, was therefore essentially zero.

\section{Discussion}

Questions have been raised about the impact of multiple herbicide applications (50 to 100) within basins larger than those typically studied in herbicide fate projects reported in the scientific literature [5]. Investigations of disturbances such as herbicide treatments are important for providing the scientific basis for sustainable watershed management and minimal impacts from continued operational use of herbicides [63] Intensive planted forestry is also an important economic activity in New Zealand and other countries like Australia, Brazil, Canada, Chile, Finland, Russia, Sweden, and the United States [64]. Therefore, in landscapes that have intense and extensive forest management, the big question becomes "Are there water quality effects that occur from multiple uses of herbicides within the same landscape and over time?" This is where a cumulative effects analysis becomes very important for both forest managers, regulators and the general public.

Hexazinone and terbuthylazine are commonly used in New Zealand's planted forests for controlling weed species at the time of Pinus radiata establishment [15]. Hexazinone is more persistent in the environment and terbuthylazine is more toxic to non-target organisms [14,15]. Hence, the New Zealand drinking water standards for these two herbicides are considerably different, 400 and $8 \mu \mathrm{g} \cdot \mathrm{L}^{-1}$, respectively.

Applications of terbuthylazine and hexazinone in Years 1 and 2 of the cumulative effects study in the Rangitaiki Basin created several situations of space crowding and time crowding (Table 1). Synergistic and indirect cumulative effects were not assessed. Nibbling was not operative as a cumulative effect since herbicide residues decreased along the stream courses due to dilutions from untreated areas and increased river flow. In addition, other water quality parameters were not measured at the scale of the herbicide applications. However, an indication of the level of potential nibbling can be viewed by examining other water quality parameters obtained by periodic sampling at the Rangitaiki guage (Table 7). Peaks of both herbicides were significantly lower than nitrogen or phosphorus and of short duration while the nitrogen and phosphorus concentrations were likely continuous. Therefore, nibbling is not suspected as being a problem for Rangitaiki's water quality.

Table 7. Comparison of modeled peak terbuthylazine and hexazinone concentrations at the Rangitaiki flow gauge with other water quality parameters [59].

\begin{tabular}{cccccc}
\hline $\begin{array}{c}\text { Total Nitrogen } \\
\left(\mu \mathrm{g} \cdot \mathrm{L}^{-3}\right)\end{array}$ & $\begin{array}{c}\text { Total Phosphorus } \\
\left(\mu \mathrm{g} \cdot \mathrm{L}^{-3}\right)\end{array}$ & $\begin{array}{c}\text { Turbidity } \\
(\mathrm{NTU})\end{array}$ & $\begin{array}{c}\text { Bacteria }(\text { E. coli) } \\
\mathbf{N o} . / \mathbf{1 0 0} \mathbf{~ m L}\end{array}$ & $\begin{array}{c}\text { Peak Terbuthylazine } \\
\left(\mu \mathrm{g} \cdot \mathrm{L}^{-3}\right)\end{array}$ & $\begin{array}{c}\text { Peak Hexazinone } \\
\left(\mu \mathrm{g} \cdot \mathrm{L}^{-3}\right)\end{array}$ \\
\hline 1089.5 & 29.5 & 1.4 & 26 & 2.044 & 0.179 \\
\hline
\end{tabular}

Herbicide use is likely to reduce other water pollutants such as sediment since as a weed control method it reduces soil disturbance and hence erosion potential $[4,65]$. Time lag was minimal according to the streamflow analyses that were part of the cumulative effects analysis and not likely to adversely affect water quality. Cross-boundary effects were incorporated to some extent in that application sites within $300 \mathrm{~m}$ of streams were assumed to provide input into the tributary stream system of the Rangitaiki River [66]. Trigger or threshold cumulative effects are generally not operative with herbicide applications as they are usually large-scale phenomena. Fragmentation is common in planted forestry landscapes and is a function of silviculture and management systems, not single treatments. 
Since some time and space crowding was observed and measured, hypothesis H1 (Some localized and short duration cumulative effects due to time crowding and space crowding will be observed in the model outputs) is accepted as an outcome of this analysis. However, the impacts on water quality were very minor as they did not produce significant increases in herbicide residue contents of streamflow or lead to New Zealand and World Health Organization drinking water standards being exceeded [55,63].

The second hypothesis (H2) proposed that the aerial herbicide applications would have no adverse effect on water quality in the upper Rangitaiki River Basin. Acceptance of this hypothesis is supported by large safety factors relative to human Acceptable Daily Intake (ADI), the New Zealand drinking water standards, Daphnia spp. exposure, and rainbow trout exposure (Tables 4 and 5). The smallest safety factors (7) are for unrealistic exposures as in the case of human ADI for ingestion of $1.0 \mathrm{~m}^{3} \cdot$ day $^{-1}$ of drinking water with residues. Low drinking water standards $\left(8 \mu \mathrm{g} \cdot \mathrm{L}^{-1}\right)$ resulted in low safety factors as in a factor of 8 for terbuthylazine. Other safety factors were huge as in $>4.420 \times 10^{6}$ for Daphnia spp. exposure to hexazinone.

There may be some concern that individuals with multiple chemical sensitivity (MCS) might react to these low levels. However, there are no clinically unique signs, laboratory tests, tissue pathology, or illness diagnostics that have been identified as unique to MCS. It is also unclear whether symptoms are physiologically or psychologically generated $[67,68]$. The World Health Organization's database on classification of disease and related health issues does not recognize MCS or environmental sensitivity as a valid diagnosis. The American Medical Association does not recognize MCS as an organic disease because of the absence of scientific studies supporting a cause-and-effect relationship between very low level exposures and the symptoms of MCS. The United States Occupational Safety and Health Administration (OSHA) states that MCS is "highly controversial" and that "there is insufficient scientific evidence to explain the relationship between the suggested causes of MCS and its symptoms."

As far as future research needs, there is a need for other cumulative effects studies in different climates, geologies, soils, hydrologic regimes, etc., to capture the range of responses to herbicide applications in NZ's planted forests. The same is true for other land uses, particularly as terbuthylazine is the most common herbicide detected in New Zealand's groundwater [69]. Although further studies are needed, this study indicates that the low frequency of herbicide use in New Zealand's planted forests could potentially offset the chemical pollution of freshwater quality from other land uses.

This analysis occurred during a dry period in the North Island of New Zealand (Figure 4), so repetition during a wet period would be helpful to determine if safety factors are in the same order of magnitude. Groundwater monitoring was not done as part of this cumulative effects analysis. It would be beneficial to incorporate groundwater in any future studies [69]. Often, financial resource and geologic condition limitations prevent this from being incorporated in cumulative effects analyses. There are more pressing science needs with surface water quality, but the questions will nevertheless remain.

\section{Conclusions}

Two commonly used forestry herbicides, Release $\mathrm{KT}^{\mathrm{TM}}$ containing terbuthylazine $\left(435 \mathrm{~g} \cdot \mathrm{L}^{-1}\right)$ and hexazinone $\left(65 \mathrm{~g} \cdot \mathrm{L}^{-1}\right)$ and Gardoprim ${ }^{\mathrm{TM}}$ containing terbuthylazine $\left(500 \mathrm{~g} \cdot \mathrm{L}^{-1}\right)$ were aerially applied at rates of 14 to $24 \mathrm{~L} \cdot \mathrm{ha}^{-1}$ in two consecutive years to a 12.5 ha reference catchment of newly planted Pinus radiata in the Bay of Plenty Region of New Zealand [30]. This application was part of a landscape-level herbicide application program to control several persistent weed species that interfere with annual reforestation. A cumulative effects analysis was conducted to determine the water quality risk within a 118,345 ha catchment of the Rangitaiki River at Mururpara. Data on herbicide movement from the monitored catchment were extrapolated to over 100 unmonitored spray sites. A spreadsheet model was then used to route the herbicide residues to the river and the analysis point at a gauging station at Murupara where long-term streamflow records were available. 
Cumulative effects modeling using an Excel spreadsheet model of chemical residue loadings and concentrations of terbuthylazine and hexazinone in the Rangitaiki River indicated that potential herbicide residues in stream waters would, for the most part, be below analytical detection limits of $0.020 \mu \mathrm{g} \cdot \mathrm{L}^{-1}$. Based on toxicological and environmental fate literature, these levels would not pose a risk to the aquatic environment or human health and safety. Safety factors for the herbicide water quality standards for daily average concentrations and instantaneous concentrations, Daphnia spp. exposure, Oncorhynchus mykiss (rainbow trout) exposure, and human Acceptable Daily Intake levels were very large.

Water quality standards (hexazinone $400 \mu \mathrm{g} \cdot \mathrm{L}^{-1}$ and terbuthylazine $\left(8 \mu \mathrm{g} \cdot \mathrm{L}^{-1}\right)$, at the level of the cumulative effects analysis (Rangitaiki gauging station at Murupara), were never exceeded. Some water-sample herbicide residue levels did exceed standards for very short periods of time [30].

The conclusion of this study is that the operational landscape level application of terbuthylazine and hexazinone monitored in the Rangitaiki Basin did not have any significant effect on water quality, human health, or exposure of aquatic species. Cumulative effects analyses of operational application of forestry herbicides elsewhere in New Zealand or the world, conducted under similar conditions and the use of Best Management Practices, are most likely to reach the same conclusions.

Acknowledgments: We would like to thank NIWA New Zealand and Trustpower for the use of the Rangitaiki flow data and also the forest management company that provided the operational data and supported this project. The Organization for Economic Cooperation and Development and SCION (Forest Research Institute Ltd.) provided research fellowships for the senior author to undertake this research. The senior author is grateful to the USDA Forest Service, Rocky Mountain Research Station, Air Water and Aquatic Environments Program for salary support and the time release for two research details to SCION. This research was supported by the Growing Confidence in Forestry's Future research programme, which is funded by the Ministry of Business, Innovation and Employment and the Forest Growers Levy Trust. This project was also supported by funding from the Undermining Weeds Project (contract C10X081).

Author Contributions: Brenda R. Baillie and Daniel G. Neary conceived and designed the field study; Brenda R. Baillie collected the reference water sample and flow data and collated or computed the input data for the model; Daniel G. Neary designed the cumulative effects model and analyzed the outputs; Daniel G. Neary and Brenda R. Baillie wrote the paper.

Conflicts of Interest: The authors declare no conflict of interest.

\section{References}

1. Scatena, F.N. Drinking water quality. In Drinking Water from Forests and Grasslands: A Synthesis of the Scientific Literature; Dissmeyer, G.E., Ed.; General Technical Report SRS-39; USDA Forest Service Southern Research Station: Asheville, NC, USA, 2000; Chapter 2; pp. 7-25.

2. Bolstad, P.V.; Swank, W.T. Cumulative impacts of land use on water quality in a southern Appalachian watershed. J. Am. Water Resour. Assoc. 1997, 33, 519-533. [CrossRef]

3. Swanson, F.J.; Scatena, F.N.; Dissmeyer, G.E.; Fenn, M.E.; Verry, E.S.; Lynch, J.A. Watershed processes-Fluxes of water, dissolved constituents, and sediment. In Drinking Water from Forests and Grasslands: A Synthesis of the Scientific Literature; Dissmeyer, G.E., Ed.; General Technical Report SRS-39; USDA Forest Service Southern Research Station: Asheville, NC, USA, 2000; Chapter 3; pp. 26-41.

4. Neary, D.G.; Ice, G.G.; Jackson, C.R. Linkages between forest soils and water quantity and quality. For. Ecol. Manag. 2009, 258, 2269-2281. [CrossRef]

5. Neary, D.G. Experimental Forest Catchment Studies Contributions to the Understanding of the Effects of Disturbances on Water Quality: Past, Present, and Future. Available online: https:/ / arizona.openrepository. com/arizona/bitstream/10150/301298/1/hwr_42-061-076.pdf (accessed on 21 November 2016).

6. Dissmeyer, G.E. (Ed.) Drinking Water from Forests and Grasslands. A Synthesis of the Scientific Literature; General Technical Report SRS-39; USDA Forest Service Southern Research Station: Asheville, NC, USA, 2000; p. 246.

7. Foley, J.A.; DeFries, R.; Asner, G.P.; Barford, C.; Bonan, G.; Carpenter, S.R.; Chapin, F.S.; Coe, M.T.; Daily, G.C.; Gibbs, H.K.; et al. Global consequences of land use. Science 2005, 309, 570-574. [CrossRef] [PubMed]

8. Baillie, B.R.; Neary, D.G. Water quality in New Zealand's planted forests: A review. N. Z. J. For. Sci. $2015,45$. [CrossRef] 
9. Larned, S.T.; Scarsbrook, M.R.; Snelder, T.H.; Norton, N.J.; Biggs, B.J.F. Water quality in low-elevation streams and rivers in New Zealand: Recent state and trends in contrasting land-cover classes. N. Z. J. Mar. Freshw. Res. 2004, 38, 347-366. [CrossRef]

10. Little, K.M.; Willoughby, I.; Wagner, R.G.; Adams, P.; Frochot, H.; Gava, J.; Gous, S.; Lautenschlager, R.A.; Örlander, G.; Sankaran, K.V.; et al. Towards reduced herbicide use in forest vegetation management. South Afr. For. J. 2006, 207, 63-79. [CrossRef]

11. Neary, D.G.; Bush, P.B.; Douglass, J.E. Offsite movement of hexazinone in stormflow and baseflow from forest watersheds. Weed Sci. 1983, 31, 543-551.

12. Neary, D.G.; Bush, P.B.; Grant, M.A. Water quality of ephemeral forest streams after site preparation with the herbicide hexazinone. For. Ecol. Manag. 1986, 14, 23-40. [CrossRef]

13. Neary, D.G. Effects of pesticide applications on forest watersheds. In Forest Hydrology and Ecology at Coweeta; Swank, W.T., Crossley, D.A., Jr., Eds.; Springer: New York, NY, USA, 1988; pp. 325-337.

14. Neary, D.G.; Michael, J.J. Herbicides-Protecting long-term sustainability and water quality in forest ecosystems. N. Z. J. For. Sci. 1996, 26, 241-264.

15. Rolando, C.A.; Garrett, L.G.; Baillie, B.R.; Watt, M.S. A survey of herbicide use and a review of environmental fate in New Zealand planted forests. N. Z. J. For. Sci. 2013, 43, 1-10. [CrossRef]

16. Garrett, L.G.; Watt, M.S.; Rolando, C.A.; Pearce, S.H. Environmental fate of terbuthylazine and hexazinone in a New Zealand planted forest Pumice soil. For. Ecol. Manag. 2015, 337, 67-76. [CrossRef]

17. Neary, D.G.; Bush, P.B.; Michael, J.L. Fate of pesticides in southern forests: A review of a decade of progress. Environ. Toxicol. Chem. 1993, 12, 411-428. [CrossRef]

18. Fagg, P.C.; James, J.M.; Flinn, D.W.; Mainey, P. Residues of Hexazinone and Four of Its Metabolites in Stream Water after Aerial Spraying of a Pinus radiata Plantation near Yarram, Victoria; Forest Commission Victoria Report; Forest Commission: Victoria, Australia, 1982; p. 9.

19. Leitch, C.J.; Flinn, D.W. Residues of hexazinone in streamwater after aerial application to an experimental catchment planted with radiata pine. Aust. For. 1983, 46, 126-131. [CrossRef]

20. Skark, C.; Zullei-Seibert, N.; Uwe, W.; Gatzemann, U.; Schlett, C. Contribution of non-agricultural pesticides to pesticide load in surface water. Pest Manag. Sci. 2004, 60, 525-530. [CrossRef] [PubMed]

21. Miller, J.H.; Bace, A.C., Jr. Streamwater Contamination after Aerial Application of a Pelletized Herbicide; Research Note SO-255; USDA Forest Service, Southern Forest Experiment Station: New Orleans, LA, USA, 1980; p. 4.

22. Neary, D. Monitoring herbicide residues in springflow after an operational application of hexazinone. South. J. Appl. For. 1983, 7, 217-223.

23. Neary, D.G.; Bush, P.B.; Douglass, J.E.; Todd, R.L. Picloram movement in an Appalachian forest watershed. J. Environ. Qual. 1985, 14, 585-592. [CrossRef]

24. Lavy, T.L.; Mattice, J.D.; Kochenderfer, J.N. Hexazinone persistence and mobility of a steep forested watershed. J. Environ. Qual. 1984, 18, 507-514. [CrossRef]

25. Bouchard, D.C.; Lavy, T.L.; Lawson, E.R. Mobility and persistence of hexazinone in a forest watershed. J. Environ. Qual. 1985, 14, 229-233. [CrossRef]

26. Michael, J.L.; Neary, D.G. Herbicide dissipation studies in southern forest ecosystems. Environ. Toxicol. Chem. 1993, 12, 405-410. [CrossRef]

27. Neary, D.G.; Michael, J.L.; Wells, M.J.M. Fate of hexazinone and picloram after herbicide site preparation in a cut-over northern hardwood forest. In Proceedings of the 1984 Annual Lake States Forest Soils Conference, L'Anse, MI, USA, 26-28 September 1984; pp. 55-72.

28. Fiore, H. Water Monitoring Report: 1992 Herbicide Application Projects: Eldorado National Forest; USDA Forest Service, Eldorado National Forest: Placerville, CA, USA, 1992; p. 27.

29. McBroom, M.W.; Louch, J.; Beasley, S.R.; Chang, M.; Ice, G.G. Runoff of silvicultural herbicides applied using best management practices. For. Sci. 2013, 59, 197-210. [CrossRef]

30. Baillie, B.R.; Neary, D.G.; Gous, S. Aquatic fate of aerially applied hexazinone and terbuthylazine in a New Zealand planted forest. J. Sustain. Watershed Sci. Manag. 2015, 2, 118-129. [CrossRef]

31. Boyle, J.R.; Wariloa, J.E.; Beschta, R.L.; Reiter, M.; Chambers, C.C.; Gibson, W.P.; Gregory, S.V.; Grizzel, J.; Hagar, J.C.; Li, J.L.; et al. Cumulative effects of forestry practices: An example framework for evaluation from Oregon, USA. Biomass Bioenergy 1997, 13, 223-245. [CrossRef]

32. National Environmental Policy Act of 1969. Available online: https://www.fws.gov/r9esnepa/ relatedlegislativeauthorities/nepa1969.pdf (accessed on 21 November 2016). 
33. Spaling, H. Cumulative effects assessment: Concepts and principles. Impact Assess. 1994, 12, $231-251$. [CrossRef]

34. Holling, C.S. Resilience and stability of ecological systems. Annu. Rev. Ecol. Syst. 1973, 4, 1-23. [CrossRef]

35. Barrett, G.W.; Van Dyn, G.M.; Odum, E.P. Stress ecology. Bioscience 1976, 26, 192-194. [CrossRef]

36. Barrett, G.W.; Rosenberg, R. (Eds.) Stress Effects on Natural Ecosystems; John Wiley: Chichester, UK; New York, NY, USA, 1976; p. 305.

37. Therivel, R.; Ross, B. Cumulative effects assessment-Does scale matter. Environ. Impact Asses. Rev. 2007, 27, 365-385. [CrossRef]

38. Neary, D.G.; Smethurst, P.J.; Baillie, B.; Petrone, K.C. Water Quality, Biodiversity, and Codes of Practice in Relation to Harvesting Forest Plantations in Streamside Management Zones; Commonwealth Scientific and Industrial Research Organization Special Report; Commonwealth Scientific and Industrial Research Organization: Canberra, Australia, 2011; p. 99.

39. Bennett, G.W.; Chorley, R.J. Environmental Systems: Philosophy, Analysis and Control; Princeton University Press: Princeton, NJ, USA, 1978; p. 624.

40. Rapport, D.J.; Regier, H.A.; Hutchinson, T.C. Ecosystem behavior under stress. Am. Nat. 1985, 125, 617-640. [CrossRef]

41. Sarmah, A.K.; Müller, K.; Ahmad, R. Fate and behavior of pesticides in the agroecosystem-A review with a New Zealand perspective. Aust. J. Soil Res. 2004, 42, 125-154. [CrossRef]

42. Beanlands, G.E.; Policansky, D.; Erckmann, W.J.; Sadar, M.H.; Orians, G.H.; O’Riordan, J. (Eds.) Cumulative Environmental Effects: A Binational Perspective; The Canadian Environmental Assessment Research Council: Ottawa, ON, Canada; The United States National Research Council: Washington, DC, USA, 1986.

43. Orians, G.H. Opening discussions-Cumulative effects: Setting the stage. In Cumulative Environmental Effects: A Binational Perspective; Beanlands, G.E., Policansky, D., Erckmann, W.J., Sadar, M.H., Orians, G.H., O'Riordan, J., Eds.; The Canadian Environmental Assessment Research Council: Ottawa, ON, Canada; The United States National Research Council: Washington, DC, USA, 1986; p. 175.

44. Molloy, L. Soils in the New Zealand Landscape: The Living Mantle, 2nd ed.; New Zealand Society of Soil Science: Canterbury, New Zealand, 1998.

45. Leonard, G.S.; Begg, J.G.; Wilson, C.J.N. (Comps.). Geology of the Rotorua Area: Institute of Geological E Nuclear Sciences 1:250,000 Geological Map 5. 1 Sheet + 102p; GNS Science: Lower Hutt, New Zealand, 2010.

46. Holdridge, L.R. Life Zone Ecology; Tropical Science Center: San Jose, Costa Rica, 1967; p. 206.

47. Quayle, A.M. The Climate and Weather of the Bay of Plenty Region; New Zealand Meteorological Service, Ministry of Transport: Wellington, New Zealand, 1984; p. 56.

48. Thompson, C.S. The Weather and Climate of the Tongariro Region; New Zealand Meteorological Service, Ministry of Transport: Wellington, New Zealand, 1984.

49. Climatemps. 2014. Available online: http://www.murupara.climatemps.com/ (accessed on 24 November 2014).

50. Porteous, A.; Mullan, B. The 2012-2013 Drought: An Assessment and Historical Perspective; Ministry of Primary Industries Technical Paper No: 2012/18; NIWA: Wellington, New Zealand, 2013; p. 57.

51. U.S. Environmental Protection Agency. Available online: http://www.epa.gov/osw/hazard/testmethods / sw846/pdfs/3510c.pdf (accessed on 21 November 2016).

52. EXCEL Spreadsheet Software. Available online: https://www.microsoftstore.com/US/Microsoft_Excel (accessed on 15 January 2015).

53. Maptoaster Topo® Version 6 Integrated Mapping. 2015. Available online: https://www.maptoaster.com/ maptoaster-topo-nz/index.html (accessed on 15 January 2015).

54. Richardson, B.; Ray, J.; Vanner, A.; Davenhill, N.; Miller, K. Nozzles for minimising aerial herbicide spray drift. N. Z. J. For. Sci. 1996, 26, 438-448.

55. New Zealand Ministry of Health. Drinking Water Standards for New Zealand 2005 (Revised 2008); Ministry of Health: Wellington, New Zealand, 2008.

56. World Health Organization. Terbuthylazine (TBA) in Drinking Water: Background Document for Development of WHO Guidelines for Drinking Water Quality; World Health Organization: Genera, Switzerland, 2003.

57. Watt, M.S.; Rolando, C.A.; Zaayman, M.; Martin, K. Adsorption of the herbicide terbuthylazine across a range of New Zealand forestry soils. Can. J. For. Res. 2010, 40, 1448-1457. [CrossRef] 
58. Ghassemi, M.; Fargo, L.; Painter, P.; Quinlivan, S.; Schofield, R.; Takata, A. Environmental fates and impacts of major forest use pesticides. In Environmental Fates and Impacts of Major Forest Use Pesticides; TRW: Redondo Beach, FL, USA; U.S. EPA Office of Pesticides and Toxic Substances: Washington, DC, USA, 1981; pp. A169-A194.

59. Durkin, P.; King, C.; Klotzbach, J. Hexazinone-Human Health and Ecological Risk Assessment_-Final Report; Syracuse Environmental Research Associates, Inc.: Fayetteville, NY, USA, 2005; p. 281.

60. Rhodes, R.C. Studies with "Velpar" Weed Killer in Water; Document No. AB29645E; DPR\# 369-039; E.I. du Pont de Nemours and Co., Inc.: Wilmington, DE, USA, 1986; Unpublished study.

61. Wang, H.; Lin, K.; Hou, Z.; Richardson, B.; Gan, J. Sorption of the herbicide terbuthylazine in two New Zealand forest soils amended with biosolids and biochars. J. Soils Sediments 2010, 10, 283-289. [CrossRef]

62. Palm, W.U.; Zetzsch, C. Investigation of the photochemistry and quantum yields of triazines using polychromatic irradiation and UV-spectroscopy as analytical tools. Int. J. Environ. Anal. Chem. 1996, 65, 313-329. [CrossRef]

63. World Health Organizaion. Guidelines for Drinking-Water Quality, 4th ed.; WHO: Geneva, Switzerland, 2011; p. 564.

64. Webb, A.A.; Bonell, M.; Bren, L.; Lane, P.N.J.; McGuire, D.; Neary, D.G.; Nettles, J.; Scott, D.F.; Stednick, J.D.; Wang, Y. Revisiting experimental catchment studies in forest hydrology. In Proceedings of the 2011 International Union of Geodesy and Geophysics XXV General Assembly, Melbourne, Australia, 6-8 July 2011; p. 234.

65. Smith, D.G.; Ruurd Maasdam, R. New Zealand's national river water quality network 1 . Design and physic-chemical characterization. N. Z. J. Mar. Freshw. Res. 1994, 28, 19-35. [CrossRef]

66. Land Air Water Aotearoa. Rangitaiki River at Old Bridge at Murupara. $2015 . \quad$ Available online: http:/ / www.lawa.org.nz/explore-data/bay-of-plenty-region/rangitaiki-river/rangitaiki-river-atold-bridge-at-murupara/ (accessed on 28 November 2014).

67. Staudenmayer, H.; Selner, J.C. Failure to assess psychopathology in patients presenting with chemical sensitivities. J. Occup. Environ. Med. 1995, 37, 704-709. [CrossRef] [PubMed]

68. Das-Munshi, J.; Rubin, G.J.; Wessely, S. Multiple chemical sensitivities: A systematic review of provocation studies. J. Allergy Clin. Immun. 2006, 118, 1257-1264. [CrossRef] [PubMed]

69. Close, M.E.; Skinner, A. Sixth national survey of pesticides in groundwater in New Zealand. N. Z. J. Mar. Freshw. Res. 2012, 46, 443-457. [CrossRef]

(c) 2016 by the authors; licensee MDPI, Basel, Switzerland. This article is an open access article distributed under the terms and conditions of the Creative Commons Attribution (CC-BY) license (http:/ / creativecommons.org/licenses/by/4.0/). 